\title{
Reviews and syntheses: Changing ecosystem influences on soil thermal regimes in northern high-latitude permafrost regions
}

\author{
Michael M. Loranty ${ }^{1}$, Benjamin W. Abbott ${ }^{2}$, Daan Blok ${ }^{3}$, Thomas A. Douglas ${ }^{4}$, Howard E. Epstein ${ }^{5}$, \\ Bruce C. Forbes ${ }^{6}$, Benjamin M. Jones ${ }^{7}$, Alexander L. Kholodov ${ }^{8}$, Heather Kropp ${ }^{1}$, Avni Malhotra ${ }^{9}$, \\ Steven D. Mamet ${ }^{10}$, Isla H. Myers-Smith ${ }^{11}$, Susan M. Natali ${ }^{12}$, Jonathan A. O'Donnell ${ }^{13}$, Gareth K. Phoenix ${ }^{14}$, \\ Adrian V. Rocha ${ }^{15}$, Oliver Sonnentag ${ }^{16}$, Ken D. Tape ${ }^{7}$, and Donald A. Walker ${ }^{17}$ \\ ${ }^{1}$ Department of Geography, Colgate University, Hamilton, NY 13346, USA \\ ${ }^{2}$ Department of Plant and Wildlife Sciences, Brigham Young University, Provo, UT 84602, USA \\ ${ }^{3}$ Department of Physical Geography and Ecosystem Science, Lund University, 22362 Lund, Sweden \\ ${ }^{4}$ U.S. Army Cold Regions Research and Engineering Laboratory Fort Wainwright, Alaska 99703, USA \\ ${ }^{5}$ Department of Environmental Sciences, University of Virginia, Charlottesville, VA 22904, USA \\ ${ }^{6}$ Arctic Centre, University of Lapland, 96101, Rovaniemi, Finland \\ ${ }^{7}$ Institute of Northern Engineering, Water \& Environmental Research Center, University of Alaska, Fairbanks, \\ AK 99775, USA \\ ${ }^{8}$ Geophysical Institute, University of Alaska Fairbanks, Fairbanks, AK, 99775 USA \\ ${ }^{9}$ Environmental Sciences Division and Climate Change Science Institute, Oak Ridge National Laboratory, \\ Oak Ridge, 37831-6301, USA \\ ${ }^{10}$ Department of Soil Science, University of Saskatchewan, Saskatoon, SK S7N 5A8, Canada \\ ${ }^{11}$ School of GeoSciences, University of Edinburgh, Edinburgh, UK \\ ${ }^{12}$ Woods Hole Research Center, Falmouth, MA 02540, USA \\ ${ }^{13}$ Arctic Network, National Park Service, Anchorage, AK 99501, USA \\ ${ }^{14}$ Department of Animal and Plant Sciences, University of Sheffield, Western Bank, Sheffield, S10 2TN, UK \\ ${ }^{15}$ Department of Biological Sciences and the Environmental Change Initiative, University of Notre Dame, \\ Notre Dame 46556, USA \\ ${ }^{16}$ Département de géographie, Université de Montréal, Montréal, H2V 2B8, Canada \\ ${ }^{17}$ Institute of Arctic Biology, University of Alaska Fairbanks, AK 99775, USA
}

Correspondence: Michael M. Loranty (mloranty@ colgate.edu)

Received: 20 April 2018 - Discussion started: 7 May 2018

Revised: 6 August 2018 - Accepted: 20 August 2018 - Published: 31 August 2018

\begin{abstract}
Soils in Arctic and boreal ecosystems store twice as much carbon as the atmosphere, a portion of which may be released as high-latitude soils warm. Some of the uncertainty in the timing and magnitude of the permafrost-climate feedback stems from complex interactions between ecosystem properties and soil thermal dynamics. Terrestrial ecosystems fundamentally regulate the response of permafrost to climate change by influencing surface energy partitioning and the thermal properties of soil itself. Here we review how Arctic and boreal ecosystem processes influence thermal dynamics in permafrost soil and how these linkages may evolve
\end{abstract}

in response to climate change. While many of the ecosystem characteristics and processes affecting soil thermal dynamics have been examined individually (e.g., vegetation, soil moisture, and soil structure), interactions among these processes are less understood. Changes in ecosystem type and vegetation characteristics will alter spatial patterns of interactions between climate and permafrost. In addition to shrub expansion, other vegetation responses to changes in climate and rapidly changing disturbance regimes will affect ecosystem surface energy partitioning in ways that are important for permafrost. Lastly, changes in vegetation and ecosystem dis- 
tribution will lead to regional and global biophysical and biogeochemical climate feedbacks that may compound or offset local impacts on permafrost soils. Consequently, accurate prediction of the permafrost carbon climate feedback will require detailed understanding of changes in terrestrial ecosystem distribution and function, which depend on the net effects of multiple feedback processes operating across scales in space and time.

\section{Introduction}

Permafrost, or perennially frozen ground, underlies approximately $24 \%$ of Northern Hemisphere land masses, primarily in Arctic and boreal regions (Brown et al., 1998). Soils in permafrost ecosystems have a seasonally thawed active layer that develops each summer. Organic carbon and nutrients in the active layer are seasonally subjected to mineralization, uptake by plants and microbes, and lateral hydrological transport. Carbon and nutrients locked in perennially frozen ground are considerably less active, often remaining isolated from global biogeochemical cycles for millennia (Froese et al., 2008). However, increases in temperature, associated with recent climatic change are warming soils in many high-latitude regions (Romanovsky et al., 2010), introducing permafrost carbon and nutrients to modern biogeochemical cycles (Schuur et al., 2015). Microbial activity may release some carbon and nutrients to the atmosphere in the form of carbon dioxide, methane, and nitrous oxide, greenhouse gases that contribute to further warming (e.g., Abbott and Jones, 2015; Koven et al., 2011; Voigt et al., 2017). While the magnitude of this permafrost-climate feedback remains uncertain, it is considered one of the largest terrestrial feedbacks of climate change, potentially enhancing humaninduced emissions by $22 \%-40 \%$ by the end of the century (Comyn-Platt et al., 2018; Schuur et al., 2013, 2015).

A major source of uncertainty in estimating the timing and magnitude of the permafrost-climate feedback is the complexity of the soil thermal response of permafrost ecosystems to atmospheric warming. Permafrost soil temperature and its response to climatic change are highly variable across space and time (Jorgenson et al., 2010), owing to multiple biophysical interactions that modulate soil thermal regimes across Arctic and boreal regions (Romanovsky et al., 2010). Moving northward, permafrost temperature and active layer thickness generally decrease, while permafrost thickness and spatial extent increase. In more northern locations, the areal distribution of permafrost may be continuous ( $>90 \%$ areal extent), whereas at lower latitudes discontinuous, sporadic, and isolated permafrost $(>50 \%-90 \%, 10 \%-50 \%$, and $<10 \%$ areal extent, respectively) (Brown et al., 1998) have large areas that are not perennially frozen. This general latitudinal gradient is interrupted by considerable local variability in active layer and permafrost thickness and temperature due to differ- ences in local climate, vegetation, soil properties, hydrology, topography, and snow characteristics. These factors can increase or decrease the responsiveness of permafrost soil temperatures to climate, mediating a high degree of spatial and temporal variability in the relationship between air and permafrost soil temperatures (Jorgenson et al., 2010; Shur and Jorgenson, 2007). Understanding how ecosystem characteristics influence local and regional permafrost temperature is critical to interpreting variability in rates of recent permafrost temperature increases (Romanovsky et al., 2010), and to predicting the magnitude and timing of the permafrost-climate feedback. However, links between permafrost and climate could fundamentally change as Arctic and boreal vegetation (e.g., Pearson et al., 2013) and disturbance regimes (e.g., Kasischke and Turetsky, 2006) respond to climate change.

In this paper, we review how ecosystem structural and functional properties influence permafrost soil thermal dynamics in Arctic and boreal regions. We focus on how ecosystem responses to a changing climate alter the thermal balance of permafrost soils (energy moving into and out of permafrost soil) and how these thermal dynamics translate into seasonal and interannual temperature shifts. Our objectives are to (1) identify and review the key mechanisms by which terrestrial ecosystem structure and function influence permafrost soil thermal dynamics; (2) characterize changes in these ecosystem properties associated with altered climate and disturbance regimes; (3) identify and characterize potential feedbacks and uncertainties arising from multiple opposing processes operating across spatial and temporal scales; and (4) identify key challenges and research questions that could improve understanding of how continued climatemediated ecosystem changes will affect soil thermal dynamics in the permafrost zone.

\section{Ecosystem controls on permafrost soil thermal dynamics}

Permafrost soil thermal regimes can be characterized by four seasonal phases annually. In spring, soil thaw onset occurs as day length increases energy inputs and air temperatures, and snow melts. Thaw onset occurs fairly rapidly, typically over a period of several days to weeks. During the summer, thaw period soils accumulate energy resulting in deepening of the active layer and warming of both frozen and unfrozen material. In autumn, soil freeze-back occurs as day length and air temperatures decrease. The length of the freeze-back period varies widely, from days to several months, and is heavily dependent on soil moisture content. Finally, the winter freezing period is characterized by energy losses to the atmosphere and declining soil temperatures until day length increases available energy in the spring and the annual cycle begins again. The permafrost soil thermal regime is complex because it varies with depth, and the four phases are connected. Key metrics used to characterize the soil thermal regime in- 
clude the length of the freeze-back and summer thaw periods, mean annual temperature, the annual amplitude of mean temperature, and the ratio of air to soil freezing/thawing degree days (i.e., $n$-factors), among others. (e.g., Cable et al., 2016; Romanovsky and Osterkamp, 1995).

Soil thermal dynamics in the permafrost zone are governed by ground-atmosphere energy exchange and internal energy transfers associated with phase changes of water and temperature gradients within the soil. The simplified thermal balance at the ground surface is the difference between net radiation $\left(R_{\mathrm{N}}\right)$ absorbed by a vegetation-, snow-, and ice-free land surface, and energy loss via turbulent sensible $(H)$, latent (LE), and ground $(G)$ heat fluxes. $R_{\mathrm{N}}$ is the difference between incoming and outgoing longwave (LW) and shortwave (SW) radiation where net LW is a function of atmospheric and surface temperatures, and net SW is a function of incoming solar radiation and surface albedo. In terrestrial ecosystems $G$ is thus modulated by vegetation function and structure, snow cover, topography, and hydrology (Betts and Ball, 1997; Eaton et al., 2001; Helbig et al., 2016b; Smith, 1975; Stiegler et al., 2016a; Zhang, 2005). Vegetation exerts strong controls on albedo, surface conductance, and surface temperature (Betts and Ball, 1997; Betts et al., 1999; Helbig et al., 2016b), and consequently partitioning of the surface energy balance into its component fluxes (Eugster et al., 2000). These energy balance controls vary diurnally, seasonally, and spatially across Arctic and boreal ecosystems (e.g., Beringer et al., 2005), and are sensitive to natural and anthropogenic disturbances (Helbig et al., 2016a).

Unlike lower-latitude ecosystems where $G$ constitutes a relatively small fraction of the surface energy balance, $G$ in permafrost regions is comparable in magnitude to gross soilatmospheric heat fluxes ( $H$ and LE) due to relatively large temperature gradients between the ground surface and permafrost table (Eugster et al., 2000; Langer et al., 2011a, b). $G$ is important because it is the transfer of heat between the ground surface and the active layer and permafrost. $G$ occurs primarily through thermal conduction, and is a function of the temperature gradient between the ground surface and the permafrost table (see Fan et al., 2011; Kane et al., 2001), and the thermal conductivity $\left(K_{\mathrm{T}}\right)$ of the soil. Thus, variability in thermal dynamics of active layer and permafrost soils are most generally controlled by factors influencing (1) the temperature gradient between the ground surface and permafrost at a given depth, and (2) the $K_{\mathrm{T}}$ of active layer and permafrost soil substrates (Fig. 1). The amount of energy available for $G$ is governed by energy dynamics of the atmosphere and overlying plant canopies, ground cover influences on albedo, $H$, and LE (Fig. 1). Ground surface temperature $T_{\mathrm{SG}}$ is different from the land surface temperature $\left(T_{\mathrm{SL}}\right)$, a measure typically used to assess ecosystem-climate interactions (e.g., Urban et al., 2013), because $T_{\mathrm{SL}}$ includes tallstatured overlying vegetation canopies, whereas $T_{\mathrm{SG}}$ includes only ground-cover vegetation (e.g., mosses and lichens), bare soil, or plant litter that functionally represents the ground sur- face. Once energy is absorbed at the ground surface and $T_{\mathrm{SG}}$ is elevated, soil $K_{\mathrm{T}}$, and the surface-permafrost temperature gradient will dictate how much of this energy is transferred downward into the soil. Here we focus on $T_{\mathrm{SG}}$ and $K_{\mathrm{T}}$ because they are more dynamic than permafrost temperature and will mediate permafrost responses to climate and associated carbon cycle consequences, particularly in the coming decades to centuries. It is also important to note that $G$ varies on diurnal, seasonal, and annual timescales. We focus on factors that affect $G$ on seasonal and annual timescales because they are indicative of permafrost warming and thawing, and are thus most relevant for understanding changes to the thermal regime that will impact greenhouse gas fluxes from the soil in the coming decades. In the following subsections we review the ecological factors that affect individual phases of the soil thermal regime and then consider interactions across the annual cycle.

\subsection{Vegetation canopy effects on $G$}

Vegetation canopies attenuate incoming solar radiation (Juszak et al., 2014, 2016), thereby reducing radiation at the ground surface and subsequently $T_{\mathrm{SG}}$. Canopy removal and addition experiments illustrate that shrub canopies insulate tundra soils in summer, maintaining soil temperatures upwards of $2{ }^{\circ} \mathrm{C}$ cooler than adjacent tall shrub-free areas (Bewley et al., 2007; Blok et al., 2010; Myers-Smith and Hik, 2013; Nauta et al., 2014). Canopy shading decreases soil temperatures in both evergreen (Fisher et al., 2016; Jean and Payette, 2014a, b; Roy-Léveillée et al., 2014) and deciduous (Fedorov et al., 2016; Iwahana et al., 2005) needleleaf boreal forests. Canopy removal experiments have resulted in substantial soil warming, permafrost thaw and subsidence in icerich tundra (Blok et al., 2010; Myers-Smith and Hik, 2013; Nauta et al., 2014) and deciduous needleleaf forests (Fedorov et al., 2016; Iwahana et al., 2005). In the latter case, ecosystem recovery and winter processes lead to permafrost stabilization in the decades after clearing (Fedorov et al., 2016). However, manipulation experiments may increase soil moisture and thus $K_{\mathrm{T}}$ (described below) via reductions in transpiration that may not occur when vegetation change occurs naturally. Increases in vegetation stature will tend to decrease $T_{\mathrm{SG}}$ resulting in local soil cooling during the summer months when plant canopies are present.

Whereas increases in tree and shrub cover reduce solar radiation at the ground surface, the increased canopy stature and complexity generally reduces canopy albedo, leading to an overall increase of the canopy $R_{\mathrm{N}}$ (Beringer et al., 2005; Chapin III et al., 2005; Loranty et al., 2011; Sturm et al., 2005). However, albedo may increase when shrubs replace bare ground or wet tundra (Blok et al., 2011b; Gamon et al., 2012) or depending on changes in community composition or structure (Williamson et al., 2016). During the growing season these albedo differences are relatively small (Juszak et al., 2016). Increased surface roughness with shrub or tree 


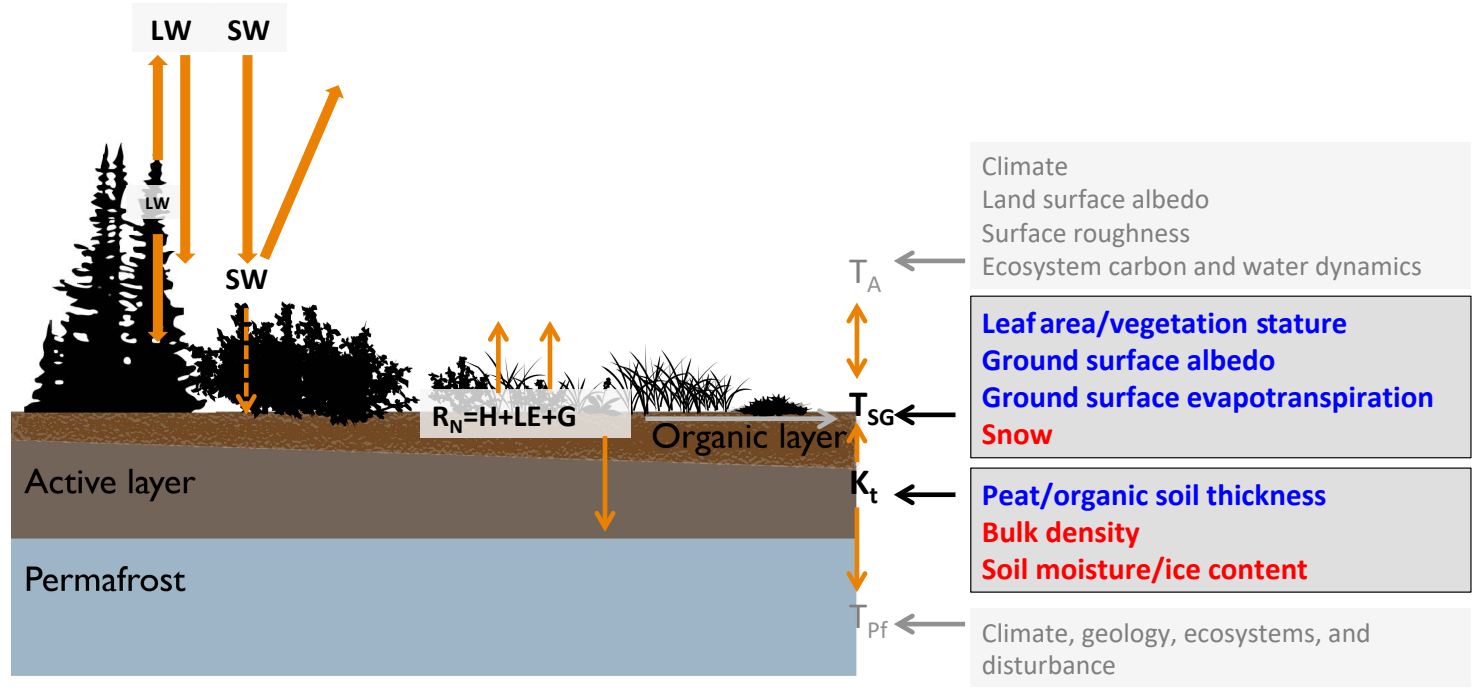

Figure 1. Key ecosystem controls on surface energy partitioning in relation to permafrost soil thermal dynamics (energy fluxes are indicated by orange arrows). Net radiation $\left(R_{\mathrm{N}}\right)$ is balanced by sensible $(H)$, latent $(\mathrm{LE})$, and ground $(G)$ heat fluxes. Ground surface temperature $\left(T_{\mathrm{SG}}\right)$ and soil thermal conductivity $\left(K_{\mathrm{T}}\right)$ exert strong controls on $G$ and are strongly influenced by a variety of ecosystem controls (indicated in dark gray boxes; red and blue text denote soil cooling and warming effects, respectively). Controls on air $\left(T_{\mathrm{A}}\right)$ and permafrost ( $\left.T_{\mathrm{Pf}}\right)$ temperatures are driven largely by climate, and we assume that ecosystem impacts on these variables are negligible on short timescales (e.g., seasonal to annual) and small spatial scales (e.g., $\mathrm{m}^{2}$ to $\mathrm{km}^{2}$ ) relative to factors highlighted in dark boxes.

expansion also enhances heat transfer to the atmosphere; however, changes in $R_{\mathrm{N}}$ and $H$ have not yet been linked to soil thermal dynamics at the ecosystem scale (Beringer et al., 2005; Göckede et al., 2017; Helbig et al., 2016b). Vegetation canopies may enhance LW radiation inputs at the ground surface by re-radiating absorbed SW radiation; however, most research has focused on LW enhancement effects on snowmelt (Webster et al., 2016), thus the growing season effects of LW enhancement on $G$ in permafrost ecosystems remain largely unstudied. Observations of lower $T_{\mathrm{SL}}$ for boreal forest canopies relative to adjacent non-forested lands due to higher LE flux (Helbig et al., 2016b; Li et al., 2015) highlight the importance of canopy controls on transpiration when considering how vegetation change affects land surface energy partitioning and atmospheric temperatures. Within vegetation types, growing seasons with higher LE reduce the amount of energy available for $H$ and $G$ (Boike et al., 2008); however, this is also related to variability in moisture inputs and can alter soil moisture dynamics, both of which also affect $G$, as discussed in following sections. In summary, during the growing season there is no clear evidence for altered ecosystem scale $G$ associated with local evaporative cooling (Li et al., 2015) or increased sensible heating as a function of canopy albedo (Beringer et al., 2005), likely because these effects are overwhelmed by canopy light attenuation.

Snow covers much of the Arctic and boreal regions for long periods each year and is a critical driver of ground temperature (Goodrich, 1982; Stieglitz, 2003). Deep and/or lowdensity snow has low $K_{\mathrm{T}}$ and thus reduces heat flux from the ground to the atmosphere during the non-growing season when air temperatures are typically colder than soil temperatures. Snow depth is initially controlled by the timing and intensity of snowfall, but wind can redistribute snow according to local topography, vegetation structure, landscape position, and wind direction, leading to high heterogeneity in snow cover and depth (Kershaw and McCulloch, 2007; Walker et al., 2001). Snow physical and insulative properties can also vary on the scale of broad ecoregions as a result of differences in air temperature, wind, precipitation, and vegetation cover (Sturm et al., 1995). For example, high thermal conductivity and density of snow in tundra relative to boreal ecosystems has been linked to differences in soil temperatures (Gouttevin et al., 2012; Mamet and Kershaw, 2013). Snow cover in the shoulder seasons (freeze-back and thaw periods) can cool soils as a result of albedo effects, but generally ground insulation from snow cover during the extended winter period dominates the snow effects on $G$. For example, across the Alaskan Arctic, ground surface temperatures are estimated to be 4 to $9{ }^{\circ} \mathrm{C}$ warmer as a result of higher snow cover (Zhang, 2005).

In tundra, shrub canopies trap blowing snow, leading to localized deepening of snow cover and higher winter soil temperatures (Domine et al., 2015; Liston et al., 2002; Marsh et al., 2010; Myers-Smith and Hik, 2013; Sturm et al., 2001, 2005). However, shrub canopies can bend in winter under the snowpack potentially leading to different amounts of snow trapping in years with heavy wet snow vs. dry snow in early winter (Marsh et al., 2010; Ménard et al., 2014). Even buried 
vegetation can lead to turbulent airflow that transports snow in complex patterns (Filhol and Sturm, 2015), which creates spatially variable ground temperatures in a given year. In some cases vegetation-snow interactions can also have a negative effect on winter ground temperature, leading to soil cooling. In northeast Siberia, large graminoid tussocks exposed above the snowpack in early winter create gaps in the insulating snow layer, which leads to lower ground temperatures, earlier active layer freezing and cooling of surface permafrost (Kholodov et al., 2012).

In the boreal forest, the presence of trees reduces the wind regime and snow redistribution (Baldocchi et al., 2000). While there is less wind-distribution in boreal forests than in the tundra, tree composition and density affect snow distribution and depth through interception of snow by the canopy branches and subsequent evaporation and sublimation. This results in lower snow inputs in dense forests and areas of shallow snow underneath individual trees (Rasmus et al., 2011). This winter effect of tree density on snow cover may, in part, explain the negative relationship found between larch stand density and ground thaw (Webb et al., 2017) and is consistent with the effects of winter warming experiments on summertime active layer dynamics (e.g., Natali et al., 2011). However, at the treeline or areas with patchy tree cover, forests can trap blowing snow, leading to decreased heat loss from soil in winter (Roy-Léveillée et al., 2014)

Tall-statured vegetation canopies that protrude above the snowpack decrease land surface albedo. While the accompanying increases in $R_{\mathrm{N}}$ will lead to sensible heating of the atmosphere at regional to local scales (Chapin III et al., 2005), they do not have a direct first order effect on $T_{\mathrm{SG}}$ or $K_{\mathrm{T}}$. In the spring thaw period when snow covers the landscape and solar radiation is high, this increase in $R_{\mathrm{N}}$ is largest (Liston et al., 2002; Marsh et al., 2010; Pomeroy et al., 2006) and may accelerate snow melt (Loranty et al., 2011; Sturm et al., 2005). This could lead to a longer snow-free season and greater $G$ during the summer thaw period; however, this snow-reducing effect can be offset by the snow-trapping effects of vegetation (Sturm et al., 2005). Changes in the length of the snow-free season because of altered canopy albedo could lead to changes in $G$; however, such an effect has not been observed. While canopy albedo does not directly influence $G$ at the ecosystem scale, regional climate feedbacks associated with albedo changes (described below) may influence permafrost thermal dynamics (Bonfils et al., 2012; Lawrence and Swenson, 2011).

Across the annual cycle, the net effect of vegetation canopies on soil thermal regimes remains unclear. Relatively few studies have simultaneously examined the role of summer energy partitioning and winter snow trapping on $G$ or soil temperatures. Myers-Smith and Hik (2013) found that winter warming associated with snow-trapping by shrub canopies elevated soil temperatures by $4-5^{\circ} \mathrm{C}$, whereas canopy shading led to $2^{\circ} \mathrm{C}$ cooling in summer. Similarly, relative to non-forested palsas, forested palsas in east- ern Canada exhibited winter soil warming associated with snow trapping but slower rates of permafrost thaw due to summer cooling associated with thicker organic layers and canopy shading (Jean and Payette, 2014a, b). Additionally, these studies observed delayed freeze-up and later spring thaw associated with late fall precipitation that resulted in complex relationships between annual air and soil temperatures and active layer depths (Jean and Payette, 2014b). Canopy snow trapping influences on winter soil temperature or $G$ is likely affected by shrub or forest patch size; however, this has not been explicitly examined. Conversely, the influence of canopy shading and LW enhancement on summer soil temperature should increase with vegetation stature and density, but vary little with patch size. At the ecosystem scale canopy influences on albedo have not been shown to impact the ground thermal regime. Thus it is likely that the magnitude of vegetation canopy influences on the annual permafrost soil thermal regime will be controlled jointly by vegetation stature, density, and patch size influences on snowredistribution. The studies mentioned above also highlight the importance covariation in over-story and under-story vegetation and canopy influences on soil moisture, which will be addressed in the following sections.

\subsection{Groundcover impacts on ground surface temperature}

Ground cover in permafrost ecosystems may include bare soil, plant litter, lichens, and mosses. Unlike vascular plant canopies, moss and lichen are in close thermal contact with the underlying soil layers so heat can be transferred from the vegetation into the soil (and vice versa) via conduction (e.g., O'Donnell et al., 2009a; Yi et al., 2009). During the growing season, differences in albedo and LE are the primary causes of variability in $T_{\mathrm{SG}}$ among ground cover types. During winter ground cover is masked by snow, and $K_{\mathrm{T}}$ is the dominant factor affecting $G$ (described below). Under moist snowfree conditions, non-vascular evaporation rates are generally high, leading to surface cooling (Heijmans et al., 2004a, b). Under dry conditions taxonomic level differences in physiological responses to drought (Heijmans et al., 2004a), can lead to large differences in $T_{\mathrm{SG}}$ (Stoy et al., 2012). Increased LE from bare soil after experimental (Blok et al., 2011a) and disturbance induced (Rocha and Shaver, 2011) moss removal illustrates the importance of non-vascular plant physiology, and highlights the relatively high potential for evaporative cooling from bare soil surfaces. Low hydraulic conductivity in mosses relative to organic and mineral soils may result in suppression of LE once moisture held in surface vegetation is depleted, whereas higher hydraulic conductivity in underlying soil layers may allow for evaporation of deeper soil moisture and increased LE observed with moss removal (Blok et al., 2011a; Rocha and Shaver, 2011). Albedo differences between common moss and lichen species may also contribute to large differences in $T_{\mathrm{SG}}$ in ways that either amplify or 
decrease the effects of physiological differences in evaporative cooling (Higgins and Garon-Labrecque, 2018; Loranty et al., 2018; Stoy et al., 2012). Variability in ground cover can correspond to large differences in $T_{\mathrm{SG}}$ that depend on the joint effects of albedo and LE, and are strongly dependent on available moisture. However, the extent to which an increase in $T_{\mathrm{SG}}$ leads to an increase in $G$ depends upon $K_{\mathrm{T}}$ of the groundcover and soil as well their soil moisture/ice content.

\subsection{Impacts of ground cover and soil properties on thermal conductivity}

Soil $K_{\mathrm{T}}$, which often includes the moss layer where present, affects the rate of heat transfer through the soil profile across a temperature gradient between the ground surface and the soil at a given depth. $K_{\mathrm{T}}$ varies throughout the soil profile with soil moisture and composition. Under dry conditions, mosses have very low $K_{\mathrm{T}}$, followed by organic and then mineral soils (Hinzman et al., 1991; O'Donnell et al., 2009a). Moss and organic soil layers have low $K_{\mathrm{T}}$ owing to high porosity, and $K_{\mathrm{T}}$ typically increases with soil bulk density (Hinzman et al., 1991; O’Donnell et al., 2009a). Mineral soils typically have higher $K_{\mathrm{T}}$ than organic soils (Hinzman et al., 1991; Kane et al., 1989; Romanovsky and Osterkamp, 2000), and fine textured clay mineral soils have lower $K_{\mathrm{T}}$ than silt or sand (Johansen, 1977). In general, ecosystems with thick moss and organic soil (e.g., peat) layers with low bulk density tend to have low $G$ and shallow active layers with all else held equal (Fisher et al., 2016; Woo et al., 2007).

Moisture content influences the thermal dynamics of soil and moss in a variety of important ways. Linear increases in $K_{\mathrm{T}}$ with moisture content (O'Donnell et al., 2009a; Soudzilovskaia et al., 2013) have strong impacts on $G$, soil temperatures, and active layer dynamics. Under saturated conditions, $K_{\mathrm{T}}$ values of mineral soils remain higher than in organic soils and mosses (Hinzman et al., 1991; O'Donnell et al., 2009a; Romanovsky and Osterkamp, 2000), so the general pattern of increasing $K_{\mathrm{T}}$ with depth and bulk density is maintained. Local- and ecosystem-scale observations of warmer soil temperatures and deeper thaw depths in areas of perennially elevated soil moisture (e.g., Curasi et al., 2016; Hinkel and Nelson, 2003; Hinkel et al., 2001; Shiklomanov et al., 2010) indicate increases in $K_{\mathrm{T}}$ outweigh the concurrent increase in specific heat capacity associated with increasing moisture content. Similarly, interannual variability in soil moisture and active layer thickness are positively related across a range of spatial scales (Iijima et al., 2010; Park et al., 2013). Across soil types, $K_{\mathrm{T}}$ increases in winter when soils freeze (Romanovsky and Osterkamp, 1997), and also with soil ice content meaning that increased soil moisture will increase summer and winter $K_{\mathrm{T}}$ (Langer et al., 2011a).

Liquid water and water vapor can also warm soils through non-conductive heat transfer (Hinkel and Outcalt, 1994; i.e., water movement; Kane et al., 2001). Here, the timing and source of water is important. For example, infiltration of snowmelt in spring does not deliver substantial heat to the soil because the water temperature is very close to freezing (Hinkel et al., 2001) and near-surface soil horizons are mostly frozen. Alternatively, condensation of water vapor in frozen soils can lead to fairly rapid temperature increases during spring melt (Hinkel and Outcalt, 1994). Heat delivery from groundwater flow has been implicated as a cause for permafrost degradation in areas of discontinuous permafrost in interior Alaska (Jorgenson et al., 2010). The hydraulic properties of soil horizons are especially important in this regard. Unsaturated peat and organic-soil horizons with large interconnected pore spaces generally promote nonconductive transport of heat in soils unless the substrate is dry enough that it absorbs water.

The relative importance of non-conductive heat transfer on permafrost thermal dynamics is difficult to determine. Observations of elevated soil temperature, active layer thickness, and thermal erosion in areas with poorly drained or inundated soils (e.g., Curasi et al., 2016; Jorgenson et al., 2010; Woo, 1990) suggest the effects of soil moisture on $K_{\mathrm{T}}$ may have stronger influences than convective processes on soil thermal dynamics. However, several recent studies indicate that heat advected in groundwater may promote permafrost thaw (de Grandpré et al., 2012; Sjöberg et al., 2016). This process is likely most important in fens, water tracks, and areas of discontinuous permafrost, and less important in areas of continuous permafrost with thin organic layers because mineral soils generally have low hydraulic conductivity. Soil moisture distribution within the soil profile is important as well; dry surface organic layers with low $K_{\mathrm{T}}$ may buffer against warmer air temperatures even though deeper soils may have high $K_{\mathrm{T}}$ associated with moisture and soil composition (Göckede et al., 2017; Rocha and Shaver, 2011). Observations of co-varying heterogeneity in soil structure, temperature, and moisture also illustrate the importance of spatio-temporal variability in soil moisture and $K_{\mathrm{T}}$ for understanding permafrost soil thermal dynamics (Boike et al., 1998).

In wet soils the large latent heat content of soil moisture can delay freezing of the active layer (i.e., extend the freezeback duration; Romanovsky and Osterkamp, 2000). The period during which soil active layer temperatures remain constant near $0^{\circ} \mathrm{C}$ as latent heat is released form soil moisture is commonly referred to as the "zero-curtain" (Outcalt et al., 1990). Longer zero-curtain periods promote warmer winter active layer and permafrost temperatures (Morse et al., 2015; Outcalt et al., 1990). Soil thaw during spring tends to occur more rapidly than freeze-back during autumn, despite the high latent heat required to thaw ground ice, likely due to increases in $K_{\mathrm{T}}$ associated with snowmelt infiltration and/or latent heat released by condensation of water vapor (Hinkel and Outcalt, 1994). Excess ground ice deeper in the active layer or permafrost requires larger amounts of latent heat energy to melt, and so typically buffer permafrost soils 
against thaw (Halsey et al., 1995). However, when this type of ground ice does melt, it can lead to an array of physical and ecological changes via thermokarst development (Mamet et al., 2017), which further alter the soil thermal regime and can promote further warming (Kokelj and Jorgenson, 2013; Osterkamp et al., 2009).

Across the seasonal cycle soil and ground cover thermal properties interact to affect the thermal regime in complex ways that vary across ecosystem types. For example, a comparison of wet and dry microsites within tundra ecosystems found warmer surface soils in dry microsites due to lower heat capacity; however, deeper soil layers in the dry microsite remained cooler because of lower thermal conductivity of dry surface soils (Göckede et al., 2017). In wet microsites greater soil moisture lengthened the fall freeze-back period meaning that soils were warmer than dry microsites; however, once soils froze, temperatures in the wet microsites dropped rapidly and became cooler than dry microsites because of higher $K_{\mathrm{T}}$ (Göckede et al., 2017). This example illustrates how covariation in vegetation and soil properties within a single ecosystems affect the soil thermal regimes in complex ways across the annual cycle.

\subsection{Interacting ecosystem influences on the soil thermal regime}

The mechanisms described in the previous sections are relatively well understood individually and at seasonal timescales. When considered in concert, the net effect of specific processes on annual ground temperatures and thermal regimes is often unclear. This is particularly true when ecological processes co-vary or have opposing effects on permafrost soil thermal dynamics. For example, is the effect of canopy shading mitigated by LW enhancement, or amplified by reductions in soil $K_{\mathrm{T}}$ resulting from plant utilization of soil moisture? Using successional gradients to answer such questions is complicated by concurrent accumulation of organic soil, canopy leaf area, and soil moisture (Jorgenson et al., 2010). Likewise, manipulative experiments nearly always involve side effects and artefacts, for example, canopy manipulations affect soil moisture, changing soil thermal properties and surface energy inputs simultaneously (Fedorov et al., 2016). In contrast, carefully designed manipulations and gradient studies still provide the best avenue for studying single and interactive processes, and for parameterizing models. While there are a number of studies that have examined the role of variation in vegetation canopy cover, soil moisture, and ground/soil thermal properties on the permafrost thermal regime, few have fully isolated the relative contribution of each process to variation in active layer thickness or soil temperatures (Jiang et al., 2015). A recent study by Fisher et al. (2016) examined the impact of multiple factors on active layer thickness in Canadian boreal forest and found overstory leaf area to be most important, followed by moss thickness and under-story leaf area. Further, this study revealed that moisture in deeper soil layers modified the impacts of vegetation, whereas surface soil moisture did not (Fisher et al., 2016). However, this study did not explicitly consider how active vegetation canopy effects on snow-cover, or soil moisture influences on freeze-back and winter soil temperature might contribute to variability in active layer depth.

Further complexity is added when processes are considered across the annual cycle. The extent to which vegetation canopy effects on snow-distribution impact growing season soil moisture, either via direct moisture inputs or affects on growing season length, has not been thoroughly investigated. A study examining interannual variability in snow cover found that growing season energy partitioning was similar in a wet-fen after winters with above- and below-average snowfall (Stiegler et al., 2016b). However, in a nearby dry heath, below average snowfall resulted in earlier snowmelt and reduced soil moisture during the lengthened growing season, which in turn suppressed LE and $G$ (Stiegler et al., 2016b). Future research should focus on disentangling complex series of interactions between vegetation, soil properties, snow redistribution, and soil moisture across annual cycles of the soil thermal regime. Covariation in vegetation and soil characteristics and their influences on soil thermal regimes within ecosystems (Boike et al., 2008) and regions (Cable et al., 2016) may help to interpret empirical relationships between ecological and thermal variables at a range of scales.

Disentangling the relative impacts of multiple ecosystem characteristics on $G$ will become increasingly important because ecological responses to continued climate warming may lead to shifts in ecosystem distribution (Abbott et al., 2016; Pearson et al., 2013), potentially resulting in novel ecosystems with no current eco-climatic analogs (MaciasFauria et al., 2012). Because ecosystems influence permafrost soil thermal dynamics in a variety of ways, shifts in ecosystem distribution will fundamentally alter rates of permafrost thaw with projected future warming. This will occur directly via altered ecosystem surface energy dynamics that affect $G$ and indirectly through changes to the surface energy balance that feed back to climate (e.g., Fig. 1). The following sections describe ongoing and anticipated ecosystem responses to climate and associated changes to soil thermal regimes via impacts on $G$, and then the associated regional to global scale atmospheric feedbacks.

\section{Implications of environmental change for permafrost thermal dynamics}

Vegetation productivity and community composition are changing in response to longer and warmer growing seasons associated with amplified climate warming across the Arctic and boreal regions. Relationships between air temperature and soil thermal regimes vary with ecosystem properties and will thus evolve as ecosystems respond to climate change. Ecosystem structural and functional characteristics 


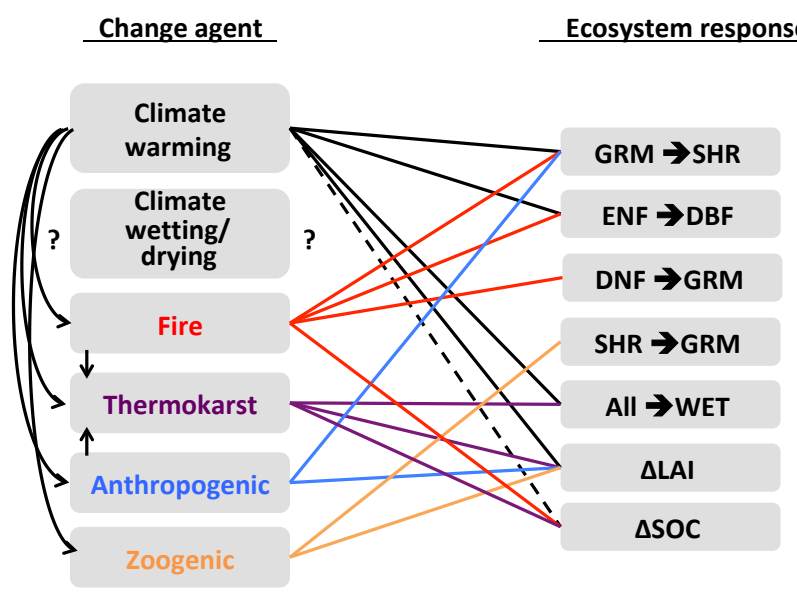

Figure 2. Summary of key drivers of ecosystem change, and the associated ecosystem responses observed (solid lines) or hypothesized (dashed lines) in permafrost ecosystems. Arrows $(\rightarrow)$ indicate transition from the current (left) to a new (right) ecosystem type, and the symbol delta $(\Delta)$ indicates a change in the associated ecosystem property. Ecosystem types are defined as follows. DBF: deciduous broadleaf forest; DNF: deciduous needleleaf forest; ENF: evergreen needleleaf forest; GRM: graminoid dominated ecosystem; SHR: shrub dominated ecosystem; WET: wetland ecosystem; All: any initial ecosystem type. Ecosystem properties are as follows. LAI: leaf area index; and SOC: soil organic carbon.

that influence soil thermal dynamics may be altered directly by ecosystem responses to climate change, or indirectly by climatic alteration of disturbance processes that in turn modify ecosystems (e.g., O'Donnell et al., 2011a). In this section, we outline key ecosystem changes arising from direct and indirect climate responses (summarized in Fig. 2), and describe how these changes are likely to affect permafrost soil thermal regimes via impacts on processes described above.

\subsection{Vegetation change in response to climate}

In tundra ecosystems, increases in vegetation productivity inferred from satellite observations (Beck and Goetz, 2011; Jia et al., 2003) have been linked to shrub expansion and accelerated annual growth at locations throughout the Arctic (Forbes et al., 2010; Frost and Epstein, 2014; Macias-Fauria et al., 2012; Tape et al., 2006). However, warming experiments indicate that productivity increases may occur without shifts in the dominant vegetation type (Elmendorf et al., 2012b; Walker et al., 2006), and dendroecological observations illustrate that shrub responses to temperature are moderated by moisture and nutrient availability and are highly heterogeneous in space and time (Ackerman et al., 2017; Myers-Smith et al., 2015; Zamin and Grogan, 2012). Despite the high degree of heterogeneity in tundra vegetation responses to warming (Elmendorf et al., 2012a), there are several consistent changes that include increased vegetation height, increased litter production, decreased moss cover (El- mendorf et al., 2012b), and increased graminoid cover in lowland permafrost features (Johansson et al., 2006; Malhotra and Roulet, 2015; Malmer et al., 2005). However, reductions in greenness in some regions (referred to as "browning") driven by, for example, reduced summer warmth index (Bhatt et al., 2013) or acute "browning events" from disturbances such as winter frost droughts (Bjerke et al., 2014; Phoenix and Bjerke, 2016) add complexity to predicting vegetation change and hence subsequent impacts on permafrost.

Below-ground vegetation dynamics are more difficult to study, but recent observations indicate that the below ground growing season length (period of unfrozen temperatures allowing for plant growth) can be greater than that above ground (Blume-Werry et al., 2015; Radville et al., 2016). These differences likely vary with depth due to effects related to the progression of soil freezing and thawing (Rydén and Kostov, 1980). Thus, rooting depth and lateral root distributions will influence the below-ground phenology differentially for deep-rooted (e.g., sedge) vs. shallow-rooted (e.g., shrub) species (Bardgett et al., 2014; Iversen et al., 2015), which may alter soil moisture via plant water uptake under future warming related vegetation changes. The changing above- and below-ground growth phenology of tundra plants (Blume-Werry et al., 2015; Iversen et al., 2015; Radville et al., 2016) could also favor the proliferation of certain functional groups or species creating potential feedbacks to vegetation change. In addition to below-ground phenology, total root production could also increase in response to warming (e.g., Xue et al., 2015). However, increased nutrient availability from warming could decrease root production relative to above-ground production (Keuper et al., 2012; Poorter et al., 2012). Improved understanding of interactions between root dynamics and soil moisture may help to understand thermal changes in permafrost soils during the summer thaw and fall freeze-back periods.

Determining the net effect of tundra vegetation productivity changes on soil thermal regimes requires improved understanding of the magnitude and spatial extent of changes in vegetation stature and rooting dynamics. Enhanced tundra vegetation productivity may reduce summer soil temperatures via ground shading and increase winter soil temperatures via effects on snow depth and density. The effect of declining moss cover will depend on the balance between reduced insulation (i.e., $K_{\mathrm{T}}$ ) and latent cooling associated with increased soil evaporation. Vegetation change may also alter organic soil accumulation rates via altered litter quality and quantity (Cornelissen et al., 2007). This overall effect on soil $K_{\mathrm{T}}$ will depend on the net effects of changing litter inputs, lability, and decomposition rates with warming (Christiansen et al., 2018; Cornelissen et al., 2007; Hobbie, 1996; Hobbie and Gough, 2004; Lynch et al., 2018). Overall the effects of vegetation change on snow redistribution and soil moisture will likely have the strongest influence on soil thermal regimes. 
Boreal forest responses to climate in recent decades were generally more heterogeneous than those observed in tundra ecosystems, due to a variety of interacting factors including species differences in physiology, disturbance regimes, and successional dynamics. Initial satellite observations of boreal forest productivity increases (Myneni et al., 1997) have slowed or even reversed in recent decades (Beck and Goetz, 2011; Guay et al., 2014). Tree ring analyses confirm productivity declines associated with temperature induced drought stress in interior Alaska boreal forests (Barber et al., 2000; Juday et al., 2015; Walker and Johnstone, 2014; Walker et al., 2015), and have been used to corroborate satellite observations (Beck et al., 2011). Similarly, drought-induced mortality has been observed at the southern margins of Canadian boreal forests (Peng et al., 2011), where correspondence between satellite and tree ring records have also been observed (Berner et al., 2011). In Siberia, positive forest responses to air temperatures observed in tree rings and satellite observations near latitudinal tree lines give way to declines in tree growth further south (Berner et al., 2013; Lloyd et al., 2010). These results are in line with ecosystem-scale observations of suppressed transpiration under high vapor pressure deficits and low soil moisture conditions (Kropp et al., 2017; Lopez C et al., 2007). More generally, forests growing on continuous permafrost exhibit more widespread productivity increases (Loranty et al., 2016), suggesting that permafrost may buffer against drought stress. However, waterlogged soil resulting from permafrost thaw can also lead to unstable soils and forest mortality (Baltzer et al., 2014; Helbig et al., 2016a; Iijima et al., 2014).

The extent to which ongoing boreal forest productivity changes influence permafrost soil thermal dynamics is not entirely clear. If forest canopy cover changes with productivity (e.g., canopy infilling or increased leaf area), then changes in ground shading and LW dynamics could alter ground thermal regimes. Increases in forest cover have been observed in northern Siberia (Frost and Epstein, 2014); however, it is unclear whether the cause is climate warming or ecosystem recovery after a fire. Conversely, productivity declines are more pronounced in high-density forests (Bunn and Goetz, 2006) and, consequently, browning trends associated with mortality in southern boreal forests (Peng et al., 2011) may increase radiation at the ground surface. Additionally, if browning is indicative of drought stress, vegetation may enhance the insulation of organic soils by further depleting of soil moisture via plant water uptake (Fisher et al., 2016). Forest mortality and declines in canopy cover in southern boreal forests as a consequence of permafrost thaw (Helbig et al., 2016a) may feedback positively to permafrost thaw. Functional changes (e.g., stomatal suppression of transpiration in response to drought) occur more quickly than structural changes, so boreal forest effects on soil moisture will likely be an important driver of changes in soil thermal regimes. In addition there has been relatively little work on how the effects of forest distribution on snow cover alters $G$ in winter, and this will also become increasingly important as forests change.

\subsection{Wildfire disturbance}

Wildfire is the dominant disturbance in boreal forests and is increasingly present in Arctic tundra. Wildfire influences surface energy dynamics via impacts on vegetation and surface soil properties, likely accelerating permafrost thaw (Brown et al., 2015; Burn, 1998; Jafarov et al., 2013; Jones et al., 2015; O'Donnell et al., 2011a; Viereck et al., 2008).Vegetation combustion and mortality increases radiation at the ground surface. The combustion and charring of moss and organic soil lowers albedo and increases $K_{\mathrm{T}}$, leading to warmer soils with deeper active layers in the decades following a fire (French et al., 2016; Liljedahl et al., 2007; Rocha and Shaver, 2011; Yoshikawa et al., 2003). In boreal forests, loss of canopy cover increases albedo during the snow-covered period (Jin et al., 2002, 2012; Lyons et al., 2008), which may result in local atmospheric cooling (Lee et al., 2011). However, such atmospheric cooling has not been linked to soil climate, and canopy loss may also result in a deeper snowpack, which inhibits ground cooling during winter (Kershaw, 2001). In general, wildfire effects on permafrost soil climate are primarily the result of altered growing season surface energy dynamics.

The magnitude of wildfire effects on soil temperature is closely linked to burn severity, as indicated by the degree of organic soil combustion and the post-fire organic horizon thickness (Kasischke and Johnstone, 2005). Post-fire recovery of the organic-soil horizon can allow recovery of soil temperature and active layer thickness to pre-fire conditions (Rocha et al., 2012). However, relatively warm discontinuous zone permafrost is often ecosystem-protected by vegetation and organic horizons (Shur and Jorgenson, 2007), thus loss or reduction of organic soil may result in the irreversible thaw or loss of permafrost (Jiang et al., 2015; Romanovsky et al., 2010). Site-based model simulations suggest that fire-driven change in organic-horizon thickness is the most important factor driving post-fire soil temperature and permafrost dynamics (Jiang et al., 2015).

Wildfire impacts on permafrost also vary spatially with ecosystems and topography. For instance, south-facing forest stands tend to burn more severely than north-facing stands (Kane et al., 2007). Further, poorly drained toe-slopes burn less severely than more moderately drained upslope landscapes. These topographic effects on burn severity can strongly influence the response of soil temperature and permafrost to fire (O'Donnell et al., 2009b). The loss of transpiration due to the combustion of trees may result in wetter soils in recently burned stands compared to unburned stands (O'Donnell et al., 2011a). However, other studies have documented drier soils in burned relative to unburned stands (Jorgenson et al., 2013), particularly at sites underlain by coarsegrained, hydrologically conductive soils. Post-fire thawing of 
permafrost can increase the hydraulic conductivity of mineral soils due to ice loss, leading to enhanced infiltration of soil water and soil drainage. Post-fire changes in soil moisture and drainage can function as either a positive or negative feedback to permafrost thaw (O'Donnell et al., 2011b). Recent evidence also indicates that mineral soil texture is an important control on post-fire permafrost dynamics (Nossov et al., 2013).

While the magnitude of fire effects on $G$ and active layer depth is typically governed by burn severity, the persistence of these changes depends on ecosystem recovery (Jorgenson et al., 2013). Albedo returns to pre-fire levels within several years after a fire (Jin et al., 2012), due to the fairly rapid recovery of vegetation (Mack et al., 2008). Recovery of moss and re-accumulation of the organic-soil horizon further facilitate recovery of soil temperatures and permafrost, and may occur within several decades (e.g., Loranty et al., 2014b). Finally, recovery of vegetation canopies over decades to centuries gradually reduces incident radiation at the ground surface to pre-fire levels. The effects of fire on $T_{\mathrm{SG}}$ and permafrost are well understood, and it may be reasonable to expect similar effects in the future that are amplified as fire exposes permafrost soils to increasingly warmer atmospheric temperatures. However, changes in the severity and extent of wildfires can result in new ecosystem dynamics with implications for permafrost that do not confer linearly from current eco-climatic conditions.

Recent warming at high latitudes has increased the spatial extent, frequency, and severity of wildfires in North America (Rocha et al., 2012; Turetsky et al., 2011) to levels that are unprecedented in recent millennia (Hu et al., 2010; Kelly et al., 2013). Fire regimes in boreal forests in Eurasia remain poorly characterized (Kukavskaya et al., 2012), though several studies indicate that fire extent and frequency are likely increasing with climate warming (Kharuk et al., 2008, 2013; Ponomarev et al., 2016). Circumpolar wildfire in the boreal forest and Arctic tundra are projected to substantially increase by the end of the century due to direct climate forcing and ecosystem responses (Abbott et al., 2016). Recovery of soil thermal regimes and permafrost after fire is strongly influenced by ecosystem recovery, and recent studies have established links between burn severity and post-fire succession (Alexander et al., 2018; Johnstone et al., 2010). Consequently, in North America burn severity is likely the dominant factor controlling the effects of wildfire on permafrost soil thermal regimes both through direct influences on soil thermal regimes and indirectly through influences on post fire succession.

In boreal North America, low-severity fires in upland black spruce forest typically foster self-replacing post-fire vegetation trajectories while high-burn severity fosters a transition to deciduous dominated forests. (Johnstone et al., 2010). In addition to changes in canopy effects on ground shading, this transition also leads to reductions in post-fire accumulation of the soil organic layer (Alexander and Mack,
2015). Observations of mean annual soil temperatures that are $1-2{ }^{\circ} \mathrm{C}$ colder in soils underlying black spruce forests compared to deciduous forests (Fisher et al., 2016; Jorgenson et al., 2010) indicate that burn severity influences on post-fire succession will lead to alternate soil temperature and permafrost recovery pathways as well.

In Siberian larch forests, post-fire recovery is impacted by fire severity and seed dispersal (Fig. 3). High burn severity fires promote high rates of seedling recruitment and subsequent forest stand density (Alexander et al., 2018; Sofronov and Volokitina, 2010) when dispersal is not limited. However, as larch are not serotinous and seed rain varies from year to year, high burn severity does not guarantee succession to high-density forests. Recovery tends to be slow and highly variable (Alexander et al., 2012b; Berner et al., 2012). Wide ranges of post-fire moss accumulation and forest regrowth have been observed, though consequences for permafrost are unclear (Furayev et al., 2001). Observed declines in permafrost thaw depth with increasing canopy cover (Webb et al., 2017) support the notion of a link between fire severity and permafrost soil thermal dynamics. However, the combined effects of fire and climatic warming and drying could lead to widespread conversion of larch forests to steppe (Tchebakova et al., 2009), whereas declines in fire could result in increased cover of evergreen needleleaf species (Schulze et al., 2012). Thus the impacts of fire on permafrost in Siberia will depend on the combined effects of climate and fire severity.

In tundra ecosystems fire is becoming increasingly common (Rocha et al., 2012). Fire-induced transitions from graminoid- to shrub-dominated ecosystems have been observed in several instances (Jones et al., 2013; Landhäusser and Wein, 1993; Racine et al., 2004), while in others recovery of graminoid-dominated ecosystems has occurred, especially when fire leads to ponding (Barrett et al., 2012; Loranty et al., 2014b; Vavrek et al., 1999). If unusually large tundra fires with high burn severity (e.g., Jones et al., 2009) occur more regularly fire induced transitions from graminoid to shrub tundra may become more common (Jones et al., 2013; Lantz et al., 2013). A shift to shrub dominance could buffer permafrost soils from continued climate warming during summer (e.g Blok et al., 2010; Myers-Smith and Hik, 2013) or promote warmer soils in winter (Lantz et al., 2013; Myers-Smith and Hik, 2013) at the ecosystem-scale, depending on how topography and the spatial distribution of shrubs impact snow redistribution (Essery and Pomeroy, 2004; Ménard et al., 2014). In addition, there is evidence that thermal erosion as a consequence of fire may facilitate shrub transitions, especially in areas of ice-rich permafrost (Bret-Harte et al., 2013; Jones et al., 2013), and the associated changes in local hydrology and topography will also impact soil thermal regimes.

Across Arctic and boreal ecosystems increased fire extent and severity will increase summer $G$ leading to warmer soils with deeper active layers that take longer to freeze-back in 


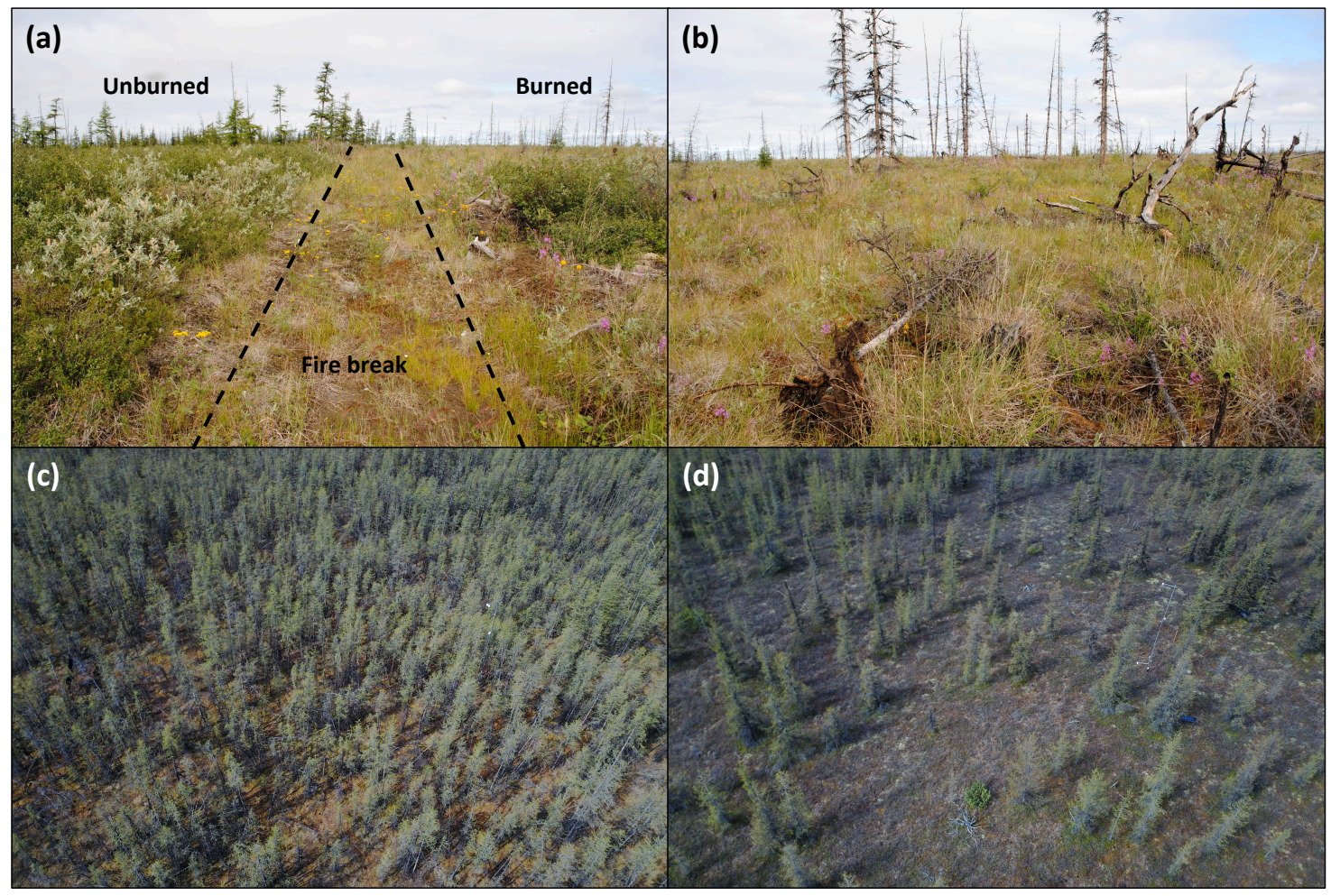

Figure 3. Impacts of fire on ecosystem structure in Siberian larch forests. A firebreak near the town of Cherskii (a) shows the contrast between burned and unburned areas $\sim 10$ years post-fire, where apparent larch and shrub recruitment failure has resulted a transition to graminoid dominance (b; detail of burned area). Nearby in a $\sim 70$ year old burn scar high-density (c) and low-density (d) forests illustrate the impacts of fire severity on canopy cover, and correspond to large differences in soil thermal regimes and active layers depths of $\sim 40 \mathrm{~cm}$ in the high-density stand and $\sim 90 \mathrm{~cm}$ in the low-density stand (Loranty and Alexander, 2014). Photos Michael M. Loranty.

fall and thus reduce the time for heat loss in winter across larger portions of the permafrost region. Post-fire ecosystem recovery will determine the trajectory of soil thermal regimes in coming decades to centuries. In tundra and Siberian larch forests shifts toward increased canopy cover may help thermal regimes recover more quickly and buffer against continued warming. However, the link between fire severity and increased canopy cover is not certain. In North American boreal forests increased deciduous cover after high severity soils may prevent full recovery of the soil thermal regime after severe fires (i.e., warmer soils) and loss of permafrost in areas where discontinuous permafrost is ecosystem protected (Jorgenson et al., 2010).

\subsection{Permafrost thaw, thermokarst disturbance, and hydrologic change}

Permafrost thaw can occur in two primary modes, depending on pre-thaw ground ice content. In terrain underlain by low ground ice content (typically $<20 \%$ by volume), the soil profile can thaw from the top down without disturbing the surface in what is termed thaw-stable permafrost degradation (Jorgenson et al., 2001). Alternatively, in icerich terrain, when ground ice volume exceeds unfrozen soil pore space (usually $>60 \%$ ), permafrost thaw causes surface subsidence or collapse, termed thermokarst (Kokelj and Jorgenson, 2013). Thermokarst is the predominant disturbance in Arctic tundra and is an important disturbance in boreal forests underlain by permafrost (Lara et al., 2016). Recent evidence indicates increasing prevalence of thermokarst features during the last half-century (Jorgenson et al., 2006, 2013; Liljedahl et al., 2016; Mamet et al., 2017), though circum-Arctic prevalence and change of thermokarst extent are poorly constrained (Lantz and Kokelj, 2008; Olefeldt et al., 2016; Yoshikawa and Hinzman, 2003). Thermokarst features form over the course of weeks to decades, can involve centimeters to meters of ground surface displacement, and typically lead to dramatic changes in ecosystem vegetation and soil properties (e.g., Douglas et al., 2016; Osterkamp et al., 2000; Wagner et al., 2018). Thermokarst could affect $20 \%-50 \%$ of the permafrost zone by the end of the century, according to projections of permafrost degradation and the distribution of ground ice (Abbott and Jones, 2015; Slater and Lawrence, 2013; Zhang et al., 2000). Upland thermokarst in the discontinuous permafrost zone already impacts $12 \%$ of the overall landscape in some areas and up to $35 \%$ of some vegetation classes (Belshe et al., 2013). 
Following initial thaw, hydrologic conditions play an important role in the subsequent evolution of thermokarst features because the high thermal conductivity of water can increase heat flux to the active layer and permafrost (Nauta et al., 2015). Lowland and upland thermokarst may have contrasting effects on surface hydrology, with lowland thermokarst initially increasing wetness (e.g., O'Donnell et al., 2012), but eventually leading to greater drainage if permafrost is completely degraded (Anthony et al., 2014). Upland thermokarst can either increase or decrease surface wetness, depending on soil conditions and local topography (Abbott and Jones, 2015; Abbott et al., 2015; Mu et al., 2017). Redistribution of water to thermokarst pits and gullies can lead to drying in adjacent areas that have not subsided (Osterkamp et al., 2009). In winter, increases in snow accumulation in thermokarst depressions insulates soils (Stieglitz, 2003).

Ecological responses to thermokarst formation can act as either positive or negative feedbacks to continued thaw, depending on how thermokarst formation affects vegetation and hydrology, including snow cover (Kokelj and Jorgenson, 2013). Active layer detachments in uplands remove vegetation and organic soil, increasing energy inputs to deeper soil layers. In upland tundra, shifts from graminoid- to shrubdominated vegetation communities have been observed with thaw, though communities varied locally with microtopography created by thermokarst features themselves (Schuur et al., 2007). In boreal forests, thermokarst and permafrost thaw can cause transitions to wetlands or aquatic ecosystems (Jorgenson and Osterkamp, 2005); whereas, vegetation community shifts are more subtle in uplands (Jorgenson et al., 2013). Permafrost thaw may also lead to a more nutrientrich environment (Harms et al., 2014; Keuper et al., 2012), but this depends on local soil properties. The succession of aquatic or terrestrial vegetation can curb thaw through negative feedbacks associated with canopy cover and organic soil accumulation and aggrade permafrost (Briggs et al., 2014). Hydrologic changes associated with thermokarst likely have a stronger influence on the soil thermal regime than associated ecosystem changes, in part because the former occur more rapidly than the latter. Under thaw stable conditions there is the possibility that enhanced vegetation productivity could lead to summer soil cooling; however, the effects on soil composition and moisture, and snow distribution will also affect the thermal regime and are as yet unclear.

\subsection{Zoogenic disturbance}

A large portion of the circumpolar Arctic is grazed by reindeer and caribou (both Rangifer tarandus L.), and their grazing and trampling causes important long-term vegetation shifts, namely inhibition of shrub proliferation (Forbes and Kumpula, 2009; Olofsson et al., 2004b, 2009; Plante et al., 2014; Väisänen et al., 2014). Besides direct consumption of lichen and green biomass, large semi-domestic reindeer herds of northwest Eurasia also exert a variety of impacts on biotic and abiotic components of Arctic and sub-Arctic tundra ecosystems that have implications for permafrost thermal regimes. For example, as reindeer reduce vertical structure of vascular and nonvascular vegetation, they tend to decrease albedo (Beest et al., 2016) and reduce thermal conductivity at the ground level (Fauria et al., 2008; Olofsson, 2006), which can lead to warmer soils (Olofsson et al., 2001, 2004b; van der Wal et al., 2001). Recent research has revealed that the consequences of climate warming on tundra carbon balance are determined by reindeer grazing history (Väisänen et al., 2014; Zimov et al., 2012). Grazing by small mammals also influences Arctic plant communities (Olofsson et al., 2004a). The extent to which ongoing vegetation change across the Arctic is a result historic grazing patterns is unclear. However, it is plausible that social and/or ecoclimatic drivers that change the distribution or behavior of grazing mammals have impacted permafrost ecosystems in ways that affect the soil thermal regime. More targeted research is necessary to elucidate links between grazing, ecosystem vegetation and soil characteristics, and soil thermal regimes.

\subsection{Anthropogenic disturbance}

The most extensive direct anthropogenic disturbances within the permafrost zone occur in three regions that have experienced widespread hydrocarbon exploration and extraction activities: the North Slope of Alaska, the Mackenzie River delta in Canada, and northwestern Russia, including the Nenets and Yamalo-Nenets Autonomous Okrugs. The types of terrestrial degradation commonly associated with the petroleum industry have historically included rutting from tracked vehicles; seismic survey trails; pipelines, drilling pads and roads and the excavation of the gravel and sand quarries necessary for their construction (Huntington et al., 2013; Walker et al., 1987). A single pass of a vehicle over thawed ground can create ruts with increased $K_{\mathrm{T}}$ due to increased bulk density and soil moisture, while altered local hydrology can drain downslope wetlands and, in both cases, lead to vegetation changes that persist for decades (Forbes, 1993, 1998). As a result of these combined factors, the increase from scale of impact to scale of response can be several orders of magnitude (Forbes et al., 2001). It has also been demonstrated that even relatively small-scale, low intensity disturbances in winter, like seismic surveys over snow-covered terrain, reduce microtopography, and increase ground temperatures and active layer thaw depths (Crampton, 1977; Kershaw, 1983).

More recently, gravel roads and pads have become common; however, this elevated infrastructure causes other unanticipated impacts to the permafrost from accumulated dust, snow drifts, and roadside flooding (Auerbach et al., 1997; Raynolds et al., 2014; Walker and Everett, 1987, 1991). Over time, the warmer environments adjacent to roads have led to strips of earlier phenology and shrub vegetation and even 
trees along both sides of most roads and buried pipeline berms in the Low Arctic (Gill et al., 2014). Aeolian sand and dust associated with gravel roads or quarries can affect tundra vegetation and soils up to $1 \mathrm{~km}$ from the point source (Forbes, 1995; Myers-Smith et al., 2006). At present, there is concern that climate warming and infrastructure are combining to enhance melting of the top surface of ice-wedges, leading to more extensive ice-wedge thermokarst (Liljedahl et al., 2016; Raynolds et al., 2014) and cryogenic landslides (Leibman et al., 2014) in areas of intensive development. The proportion of permafrost ecosystems affected by anthropogenic disturbance is not well quantified, but it will continue to increase in coming decades.

\section{Local vs. regional ecosystem feedbacks on permafrost thermal dynamics}

Interactions between ecosystem scale microclimate feedbacks and regional or global climate feedbacks stemming from ecological change are complex and represent a key source of uncertainty related to understanding permafrost soil responses to continued climate warming. If changing ecosystem characteristics influencing permafrost thermal dynamics described above are widespread, the accompanying changes in land surface water and energy exchange will feed back to influence regional climate, and changes in greenhouse gas dynamics will feed back on global climate (Chapin III et al., 2000b). Therefore, ecosystem changes that alter local permafrost soil thermal dynamics may also lead to regional and global climate feedbacks that compound or offset ecosystem-scale effects (Table 1).

\subsection{Regional biogeochemical climate feedbacks}

The net biogeochemical climate effects of ecosystem change across permafrost regions will be a balance of changes in $\mathrm{CO}_{2}$ uptake that accompany shifts in vegetation, and changes in $\mathrm{CO}_{2}$ and $\mathrm{CH}_{4}$ release associated with shifts in autotrophic and heterotrophic respiration, and fire and thermokarst disturbance. These feedback effects will be global in extent and will not contribute directly to regional variability in permafrost thaw because greenhouse gasses are well mixed in the atmosphere. Changes in the net $\mathrm{CO}_{2}$ balance remain uncertain, but a recent expert survey suggests that over the next century increases in vegetation productivity may not be large enough to offset increases in carbon release to the atmosphere (Abbott et al., 2016). In tundra ecosystems, this conclusion is in line with projections of future biomass distribution (Pearson et al., 2013) and atmospheric inversions showing that increased autumn $\mathrm{CO}_{2}$ efflux offsets increases in uptake during the growing season (Commane et al., 2017; Welp et al., 2016). In boreal forests, carbon cycle changes are more complex; long-term trends in the annual amplitude of atmospheric $\mathrm{CO}_{2}$ concentrations (Forkel et al., 2016; Graven et al., 2013) suggest increases in biological activity while satellite observations and tree ring analyses suggest widespread declines in productivity (Beck et al., 2011). Further, model analyses indicate a weakening terrestrial carbon sink associated with declining uptake, increases in respiration, and disturbance (Hayes et al., 2011), which is crucially important in boreal forests (Bond-Lamberty et al., 2013).

The net $\mathrm{CO}_{2}$ effect of wildfire has typically been considered to be close to zero for evergreen needleleaf forests in interior Alaska over historic fire return intervals (Randerson et al., 2006). However, the combined effects of climate warming and fire tend to reduce ecosystem carbon storage by thawing permafrost (Douglas et al., 2014; Harden et al., 2000; O'Donnell et al., 2011b). Model simulations that include permafrost dynamics indicate ecosystem carbon losses may become larger in the future with continued warming and intensification of the fire regime, particularly for dry upland sites (Genet et al., 2013; Jafarov et al., 2013). These studies do not account for potential changes in post-fire vegetation communities (Alexander et al., 2012a); however, the net effects of vegetation shifts on ecosystem carbon storage appear to be minimal (Alexander and Mack, 2015). In tundra ecosystems larger and more severe fires lead to large soil C losses (Mack et al., 2011) that may be sustained over time due to permafrost thaw (Jones et al., 2013, 2015). Taken together, this evidence suggests that fire will likely lead to net carbon losses in the coming decades to centuries across the permafrost region, thus acting as a positive feedback to climate warming with associated effects on permafrost soils (Abbott et al., 2016). The biophysical climate feedbacks associated with fire are more immediate and will be stronger than the carbon cycle feedbacks (Randerson et al., 2006).

The effects of thermokarst on greenhouse gas dynamics depend largely on associated hydrological changes. With increased drainage and surface drying, increased oxidation rates reduce carbon accumulation (Robinson and Moore, 2000) and enhance $\mathrm{CO}_{2}$ release (Frolking et al., 2006), and reduce $\mathrm{CH}_{4}$ production (Abbott and Jones, 2015). When ground thaw is associated with increased soil saturation, $\mathrm{CH}_{4}$ production and emissions are increased (Abbott and Jones, 2015; Johansson et al., 2006; Malhotra and Roulet, 2015; Natali et al., 2015; Olefeldt et al., 2012), which can shift tundra from a net $\mathrm{CH}_{4}$ sink (Jorgensen et al., 2015) into a $\mathrm{CH}_{4}$ source (Nauta et al., 2015). Thermokarst may also increase lateral transport of soil organic matter, which can decrease $\mathrm{CO}_{2}$ release (Abbott and Jones, 2015) and alter carbon processing downslope. Thermokarst lakes emit $\mathrm{CH}_{4}$, particularly along actively thawing lake margins (Walter et al., 2007, 2008), and $\mathrm{CO}_{2}$ (Algesten et al., 2004; Kling et al., 1991). However, at millennial timescales, thermokarst lakes can sequester carbon as lake sediments and peat accumulate (Anthony et al., 2014; Jones et al., 2012). Currently, thermokarst landscapes comprise upwards of $20 \%$ of the permafrost region (Olefeldt et al., 2016); however, their current and fu- 
Table 1. Key ecosystem changes, associated drivers, and feedback effects on local soil climate and regional to global climate.

\begin{tabular}{|c|c|c|c|}
\hline Ecosystem change & Drivers of change $^{1}$ & $\begin{array}{l}\text { Local soil temperature } \\
\text { feedbacks }^{2}\end{array}$ & Regional-global climate feedbacks ${ }^{3}$ \\
\hline $\begin{array}{l}\text { Canopy cover/density } \\
\text { increases more likely, unless } \\
\text { widespread wetting occurs or } \\
\text { under certain conditions after } \\
\text { fire. }\end{array}$ & $\begin{array}{l}\text { Climate warming }(+/-) \\
\text { Hydrologic change }(?) \\
\text { Fire severity }(+/-) \\
\text { Thermokarst }(-) \\
\text { Permafrost thaw }(+) \\
\text { Grazing }(-/ ?) \\
\text { Anthropogenic }(+/ ?)\end{array}$ & $\begin{array}{l}\mathbf{K}_{\boldsymbol{T}}-\text { Snow trapping } \\
\mathbf{T}_{\mathbf{S G}}-\mathbf{L W} \text { enhancement } \\
T_{\mathrm{SG}}-\text { Ground shading } \\
K_{\mathrm{T}}-\text { Soil moisture utilization }\end{array}$ & $\begin{array}{l}\text { Albedo } \\
\text { Carbon sequestration } \\
\text { Increased evapotranspiration }\end{array}$ \\
\hline $\begin{array}{l}\text { Soil moisture } \\
\text { uncertain; dependent on veg- } \\
\text { etation, soil, climate, topogra- } \\
\text { phy, ground ice, and whether } \\
\text { permafrost is continuous }\end{array}$ & $\begin{array}{l}\text { Climate warming }(+/-) \\
\text { Hydrologic change }(+) \\
\text { Fire severity }(+/-) \\
\text { Thermokarst }(+/-) \\
\text { Permafrost thaw }(-) \\
\text { Anthropogenic }(+/ ?)\end{array}$ & $\begin{array}{l}\mathbf{K}_{\mathbf{T}} \\
T_{\mathrm{SG}}-\text { evaporation }\end{array}$ & $\begin{array}{l}\text { Greenhouse gas emissions } \\
\text { Increased evapotranspiration } \\
\text { Carbon sequestration }\end{array}$ \\
\hline
\end{tabular}

${ }^{1}$ Parentheses indicate whether driver is likely to cause an increase (+) or decrease (-) in ecosystem properties, or if the direction of the relationship is unclear (?). ${ }^{2}$ Effects of changing ecosystems property on local soil temperatures; bold typeface indicates a positive feedback (warming) and italics indicate a negative feedback (cooling). ${ }^{3}$ Effects of changing ecosystems property on regional and global climate; bold typeface indicates a positive feedback (warming), italics indicate a negative feedback (cooling), and normal text indicates that the direction of the feedback is unclear.

ture impacts on the global carbon balance remain poorly constrained.

\subsection{Regional biophysical climate feedbacks}

The biophysical effects of ecosystem change arising from shifts in surface energy partitioning have climate feedback effects at scales ranging from local to regional and global. Whereas biogeochemical climate feedbacks will influence global temperature in conjunction with many other carbon cycle processes, biophysical feedbacks operating at local and regional scales are likely to influence the spatial and temporal patterns of permafrost thaw with continued warming. As described in the previous sections, changes in vegetation composition and structure alter soil thermal dynamics via changes in $G$ during the snow-free season (Beringer et al., 2005; Chapin III et al., 2000a). However, changes in $G$ associated with vegetation change will also be accompanied by changes in $H$ and LE that may feedback to $G$, depending upon the scale of impact.

Decadal ecosystem responses to climate inferred from "greening" or "browning" trends are the most spatially pervasive change affecting vegetation in the permafrost zone (Loranty et al., 2016). Increases in leaf area and/or vegetation stature will generally reduce albedo, and these effects are particularly pronounced during the spring and fall if enhanced productivity leads to increased snow-masking by vegetation (Loranty et al., 2014a; Sturm et al., 2005). Reductions in albedo will lead to sensible heating of the atmosphere (Chapin III et al., 2005) that may counteract the effects of canopy shading on $G$, if albedo reduction occurs at sufficiently large spatial scales (Bonfils et al., 2012; Lawrence and Swenson, 2011). The magnitude and spatial extent of vegetation height increases are crucial to determine the net feedback strength, but these quantities remain largely unknown.

A second important but relatively unexplored feedback relates to evaporative cooling of the land surface associated with increases in LE (Helbig et al., 2016b; but see Swann et al., 2010). Productivity increases are likely accompanied through increases in evapotranspiration (Zhang et al., 2009), which have been shown to mitigate temperature increases at global scales by increased cloud cover that reduces incoming short-wave radiation reaching the Earth's surface (Zeng et al., 2017). During the growing season, this cooling could effectively reduce the degree of atmospheric sensible heating associated with increased albedo, and would be particularly important if there is no change in snow masking by vegetation (e.g., greening in tundra without shrub expansion or in closed canopy boreal forest). However, the extent to which latent cooling with enhanced productivity may offset sensible heating associated with albedo decreases is uncertain for 
several reasons. First, model experiments simulating shrub expansion, for example, utilize canopy parameterizations for deciduous boreal tree species, because Arctic shrub canopy physiology has not been thoroughly characterized (e.g., Bonfils et al., 2012). Second, existing observations indicate an increasing degree of stomatal control on evapotranspiration with vegetation stature (Eugster et al., 2000; Kasurinen et al., 2014), indicating that LE will not necessarily continue to increase with climate warming, which is supported by the emergence of browning trends. Additionally, climatic changes in Arctic hydrology are highly uncertain and likely to vary spatially (Francis et al., 2009), meaning that LE may be limited by hydrology in some places but not others. Lastly, disturbance processes will also alter surface energy dynamics through short-term direct impacts on ecosystem structure and long-term impacts on post-disturbance succession (as described above).

\section{Conclusions}

The effects of climatic change on permafrost thermal dynamics depend directly on terrestrial ecosystem properties, which mediate surface energy partitioning and soil thermal characteristics. Relationships between permafrost and climate vary spatially with ecosystem properties and processes, and these patterns vary through time on event to millennial timescales. The changing nature of permafrost thermal regimes will be driven by surface energy feedbacks operating on local-, regional-, and global-scales. Complex interactions among many of these feedbacks create uncertainty surrounding the timing and magnitude of the permafrost carbon feedback.

Continued ecosystem-scale research focused on several key process interactions will improve our understanding of ecological influences on soil thermal regimes. The influence of plant water use on spatial and temporal variability in soil moisture is unclear. Future work should seek to elucidate interactions between vegetation and soil moisture. The extent to which changes in decomposition rates and litter substrate quantity and quality alter the insulating effects of ground cover and the soil organic layer is also unclear and could benefit from continued research. More research on relationships between the spatial distribution of vegetation canopies and the insulative properties of snow is also needed, especially in boreal forests. Lastly, more studies should involve year-round data collection focused on understanding timelags and the cumulative effects of seasonal processes. In particular the net thermal effects of canopy shading vs. snowtrapping, seasonally lagged effects of snow cover, and seasonally lagged effects of soil moisture could all be better understood through focused observational studies.

Improved process level understanding of ecosystem influences on soil thermal regimes will not be useful for predicting the fate of permafrost carbon unless the processes that control the timing, extent, and trajectories of ecosystem change are known. There has been a strong focus on graminoid-shrub transitions in tundra ecosystems, yet there are a number of other potential vegetation transitions, many mediated by disturbance, with equally important implications. Changes in boreal forest structure and function underlying productivity trends need to be elucidated. Continued work focused on understanding how changing fire regimes influence soils and post-fire succession is also important, especially in tundra and Siberian boreal forests. These changes are not spatially isolated, and compounding disturbances will likely become increasingly important to understand. In addition to vegetation changes, constraining the proportion of landscapes affected by drying vs. waterlogging associated with initial permafrost thaw is central to predicting both soil organic matter stocks and vegetation responses to climate warming. Whether precipitation increases or decreases with climate warming remains highly uncertain, and this will exert strong influence on vegetation and ecosystem responses to climate as well as disturbance mediated ecosystem changes.

Lastly, changes in ecosystem vegetation and soil characteristics that occur over sufficiently large spatial scales will affect soil thermal regimes via feedbacks to regional and global climate with the potential to amplify or attenuate local ecosystem-scale feedbacks. For example, could wetland expansion associated with widespread permafrost thaw lead to regional cooling through increased albedo, or might warming as a result of increased methane emissions offset this? Could increased evapotranspiration associated with enhanced vegetation productivity lead to surface cooling and cloud formation that cools soils in summer, or might the rise in atmospheric water vapor increase late summer precipitation and extend the fall freeze-back period? Complex feedback processes such as these will likely affect the trajectory of permafrost responses to climate. Continued efforts to understand the fate of permafrost in response to climate will require integrated analyses of processes affecting permafrost soil thermal regimes, changing circumpolar ecosystem distributions, and the net effects of resulting climate feedbacks operating across a range of spatial and temporal scales.

Data availability. Data referenced in Fig. 3 are available at https://doi.org/10.18739/A2CD3V (Loranty and Alexander, 2014).

Author contributions. MML conceived and led the study. All authors contributed to writing and editing the manuscript.

Competing interests. The authors declare that they have no conflict of interest. 
Acknowledgements. This project benefited from input from members of the Permafrost Carbon Network (http://permafrostcarbon.org, last access: 30 August 2018). Supporting funding for the Permafrost Carbon Network was provided by the National Science Foundation Network grant no. 955713 and the National Science Foundation Study of Environmental Arctic Change (SEARCH) grant nos. PLR-1304464 and 1331083. MML was supported with funding from the U.S. National Science Foundation grant no. PLR-1417745. DB was supported by The Swedish Research Council (2015-00465) and Marie Skłodowska Curie Actions co-funding (INCA 600398). TAD acknowledges support from the U.S. Army Basic Research (6.1) Program. BCF was supported by the Academy of Finland (decision no. 256991) and JPI Climate (decision no. 291581). IMS received support from UK Natural Environment Research Council ShrubTundra Grant (NE/M016323/1). Any use of trade, product, or firm names is for descriptive purposes only and does not imply endorsement by the US Government. We thank two anonymous reviewers for comments that helped improve this manuscript.

Edited by: Kirsten Thonicke

Reviewed by: two anonymous referees

\section{References}

Abbott, B. W. and Jones, J. B.: Permafrost collapse alters soil carbon stocks, respiration, $\mathrm{CH}_{4}$, and $\mathrm{N}_{2} \mathrm{O}$ in upland tundra, Glob. Change Biol., 21, 4570-4587, https://doi.org/10.1111/gcb.13069, 2015.

Abbott, B. W., Jones, J. B., Godsey, S. E., Larouche, J. R., and Bowden, W. B.: Patterns and persistence of hydrologic carbon and nutrient export from collapsing upland permafrost, Biogeosciences, 12, 3725-3740, https://doi.org/10.5194/bg-12-3725-2015, 2015.

Abbott, B. W., Jones, J. B., Schuur, E. A. G., Chapin III, F. S., Bowden, W. B., Bret-Harte, M. S., Epstein, H. E., Flannigan, M. D., Harms, T. K., Hollingsworth, T. N., Mack, M. C., Mcguire, A. D., Natali, S. M., Rocha, A. V., Tank, S. E., Turetsky, M. R., Vonk, J. E., Wickland, K. P., Aiken, G. R., Alexander, H. D., Amon, R. M. W., BENSCOTER, B. W., Bergeron, Y., Bishop, K., Blarquez, O., Bond-Lamberty, B., Breen, A. L., Buffam, I., Cai, Y., Carcaillet, C., Carey, S. K., Chen, J. M., Chen, H. Y. H., Christensen, T. R., Cooper, L. W., Cornelissen, J. H. C., de Groot, W. J., Deluca, T. H., Dorrepaal, E., Fetcher, N., Finlay, J. C., Forbes, B. C., French, N. H. F., Gauthier, S., Girardin, M. P., Goetz, S. J., Goldammer, J. G., Gough, L., Grogan, P., Guo, L., Higuera, P. E., Hinzman, L., Hu, F. S., Hugelius, G., Jafarov, E. E., Jandt, R., Johnstone, J. F., Karlsson, J., Kasischke, E. S., Kattner, G., Kelly, R., Keuper, F., Kling, G. W., Kortelainen, P., Kouki, J., Kuhry, P., Laudon, H., Laurion, I., Macdonald, R. W., Mann, P. J., Martikainen, P. J., McClelland, J. W., Molau, U., Oberbauer, S. F., Olefeldt, D., Pare, D., Parisien, M.-A., Payette, S., Peng, C., Pokrovsky, O. S., Rastetter, E. B., Raymond, P. A., Raynolds, M. K., Rein, G., Reynolds, J. F., Robards, M., Rogers, B. M., Schädel, C., Schaefer, K., Schmidt, I. K., Shvidenko, A., Sky, J., Spencer, R. G. M., Starr, G., Striegl, R. G., Teisserenc, R., Tranvik, L. J., Virtanen, T., Welker, J. M., and Zimov, S. A.: Biomass offsets little or none of permafrost carbon release from soils, streams, and wildfire: an expert assessment, Environ. Res.
Lett., 11, 1-13, https://doi.org/10.1088/1748-9326/11/3/034014, 2016.

Ackerman, D., Griffin, D., Hobbie, S. E., and Finlay, J. C.: Arctic shrub growth trajectories differ across soil moisture levels, Glob. Change Biol., 69, 130-139, https://doi.org/10.1111/gcb.13677, 2017.

Alexander, H. D. and Mack, M. C.: A Canopy Shift in Interior Alaskan Boreal Forests: Consequences for Above-and Belowground Carbon and Nitrogen Pools during Post-fire Succession, Ecosystems, 19, 98-114, https://doi.org/10.1007/s10021015-9920-7, 2015.

Alexander, H. D., Mack, M. C., Goetz, S. J., Beck, P. S. A., and Belshe, E. F.: Implications of increased deciduous cover on stand structure and aboveground carbon pools of Alaskan boreal forests, Ecosphere, 3, 1-21, https://doi.org/10.1890/ES1100364.1, 2012a.

Alexander, H. D., Mack, M. C., Goetz, S. J., Loranty, M. M., Beck, P. S., Earl, K., Zimov, S., Davydov, S., and Thompson, C. C.: Carbon Accumulation Patterns During Post-Fire Succession in Cajander Larch (Larix cajanderi) Forests of Siberia, Ecosystems, 15, 1065-1082, https://doi.org/10.1007/s10021-012-95676, 2012b.

Alexander, H. D., Natali, S. M., Loranty, M. M., Ludwig, S. M., Spektor, V. V., Davydov, S., Zimov, N. S., Trujillo, I., and Mack, M. C.: Impacts of increased soil burn severity on larch forest regeneration on permafrost soils of far northeastern Siberia, Forest Ecol. Manag., 417, 144-153, https://doi.org/10.1016/j.foreco.2018.03.008, 2018.

Algesten, G., Sobek, S., Bergström, A. K., Ågren, A., Tranvik, L. J., and Jansson, M.: Role of lakes for organic carbon cycling in the boreal zone, Glob. Change Biol., 10, 141-147, 2004.

Anthony, K. M. W., Zimov, S. A., Grosse, G., Jones, M. C., Anthony, P. M., III, F. S. C., Finlay, J. C., Mack, M. C., Davydov, S., Frenzel, P., and Frolking, S.: A shift of thermokarst lakes from carbon sources to sinks during the Holocene epoch, Nature, 511, 452-456, https://doi.org/10.1038/nature13560, 2014.

Auerbach, N. A., Walker, M. D., and Walker, D. A.: Effects of Roadside Disturbance on Substrate and Vegetation Properties in Arctic Tundra, Ecol. Appl., 7, 218-235, 1997.

Baldocchi, D., Kelliher, F., Black, T., and Jarvis, P.: Climate and vegetation controls on boreal zone energy exchange, Glob. Change Biol., 6, 69-83, 2000.

Baltzer, J. L., Veness, T., Chasmer, L. E., Sniderhan, A. E., and Quinton, W. L.: Forests on thawing permafrost: fragmentation, edge effects, and net forest loss, Glob. Change Biol., 20, 824834, https://doi.org/10.1111/gcb.12349, 2014.

Barber, V. A., Juday, G. P., and Finney, B. P.: Reduced growth of Alaskan white spruce in the twentieth century from temperature-induced drought stress, Nature, 405, 668-673, https://doi.org/10.1139/x88-010, 2000.

Bardgett, R. D., Mommer, L., and De Vries, F. T.: Going underground: root traits as drivers of ecosystem processes, Trends Ecol. Evol., 29, 692-699, https://doi.org/10.1016/j.tree.2014.10.006, 2014.

Barrett, K., Rocha, A. V., van de Weg, M. J., and Shaver, G.: Vegetation shifts observed in arctic tundra 17 years after fire, Remote Sens. Lett., 3, 729-736, https://doi.org/10.1080/2150704X.2012.676741, 2012. 
Beck, P. S. A. and Goetz, S. J.: Satellite observations of high northern latitude vegetation productivity changes between 1982 and 2008: ecological variability and regional differences, Environ. Res. Lett., 6, 045501, https://doi.org/10.1088/17489326/7/2/029501, 2011.

Beck, P. S. A., Juday, G. P., Alix, C., Barber, V. A., Winslow, S. E., Sousa, E. E., Heiser, P., Herriges, J. D., and Goetz, S. J.: Changes in forest productivity across Alaska consistent with biome shift, Ecol. Lett., 14, 373-379, https://doi.org/10.1111/j.14610248.2011.01598.x, 2011.

Belshe, E. F., Schuur, E. A. G., and Grosse, G.: Quantification of upland thermokarst features with high resolution remote sensing, Environ. Res. Lett., 8, 035016, https://doi.org/10.1088/17489326/8/3/035016, 2013.

Beringer, J., Chapin, F. S., Thompson, C. C., and Mcguire, A. D.: Surface energy exchanges along a tundra-forest transition and feedbacks to climate, Agr. Forest Meteorol., 131, 143-161, https://doi.org/10.1016/j.agrformet.2005.05.006, 2005.

Berner, L. T., Beck, P. S. A., Bunn, A. G., Lloyd, A. H., and Goetz, S. J.: High-latitude tree growth and satellite vegetation indices: Correlations and trends in Russia and Canada (1982-2008), J. Geophys. Res., 116, G01015, https://doi.org/10.1029/2010jg001475, 2011.

Berner, L. T., Beck, P. S. A., Loranty, M. M., Alexander, H. D., Mack, M. C., and Goetz, S. J.: Cajander larch (Larix cajanderi) biomass distribution, fire regime and post-fire recovery in northeastern Siberia, Biogeosciences, 9, 3943-3959, https://doi.org/10.5194/bg-9-3943-2012, 2012.

Berner, L. T., Beck, P. S. A., Bunn, A. G., and Goetz, S. J.: Plant response to climate change along the forest-tundra ecotone in northeastern Siberia, Glob. Change Biol., 19, 3449-3462, https://doi.org/10.1111/gcb.12304, 2013.

Betts, A. K. and Ball, J.: Albedo over the boreal forest, J. Geophys. Res., 102, 28901-28909, 1997.

Betts, A. K., Goulden, M., and Wofsy, S.: Controls on evaporation in a boreal spruce forest, J. Climate, 12, 1601-1618, 1999.

Bewley, D., Pomeroy, J., and Essery, R.: Solar Radiation Transfer Through a Subarctic Shrub Canopy, Arct. Antarct. Alp. Res., 39, 365-374, 2007.

Bhatt, U., Walker, D., Raynolds, M., Bieniek, P., Epstein, H., Comiso, J., Pinzon, J., Tucker, C., and Polyakov, I.: Recent Declines in Warming and Vegetation Greening Trends over Pan-Arctic Tundra, Remote Sensing, 5, 4229-4254, https://doi.org/10.3390/rs5094229, 2013.

Bjerke, J. W., Karlsen, S. R., Høgda, K. A., Malnes, E., Jepsen, J. U., Lovibond, S., Vikhamar-Schuler, D., and Tømmervik, H.: Record-low primary productivity and high plant damage in the Nordic Arctic Region in 2012 caused by multiple weather events and pest outbreaks, Environ. Res. Lett., 9, 084006, https://doi.org/10.1088/1748-9326/9/8/084006, 2014.

Blok, D., Heijmans, M., Schaepman-Strub, G., Kononov, A., Maximov, T., and Berendse, F.: Shrub expansion may reduce summer permafrost thaw in Siberian tundra, Glob. Change Biol., 16, 1296-1305, 2010.

Blok, D., Heijmans, M. M. P. D., Schaepman-Strub, G., Ruijven, J., Parmentier, F. J. W., Maximov, T. C., and Berendse, F.: The Cooling Capacity of Mosses: Controls on Water and Energy Fluxes in a Siberian Tundra Site, Ecosystems, 14, 1055-1065, https://doi.org/10.1007/s10021-011-9463-5, 2011a.
Blok, D., Schaepman-Strub, G., Bartholomeus, H., Heijmans, M. M., Maximov, T. C., and Berendse, F.: The response of Arctic vegetation to the summer climate: relation between shrub cover, NDVI, surface albedo and temperature, Environ. Res. Lett., 6, 035502, https://doi.org/10.1088/1748-9326/6/3/035502, $2011 \mathrm{~b}$.

Blume-Werry, G., Wilson, S. D., Kreyling, J., and Milbau, A.: The hidden season: growing season is $50 \%$ longer below than above ground along an arctic elevation gradient, New Phytol., 209, 978-986, https://doi.org/10.1111/nph.13655, 2015.

Boike, J., Roth, K., and Overduin, P. P.: Thermal and hydrologic dynamics of the active layer at a continuous permafrost site (Taymyr Peninsula, Siberia), Water Resour. Res., 34, 355-363, https://doi.org/10.1029/97WR03498, 1998.

Boike, J., Wille, C., and Abnizova, A.: Climatology and summer energy and water balance of polygonal tundra in the Lena River Delta, Siberia, J. Geophys. Res., 113, G03025, https://doi.org/10.1029/2007JG000540, 2008.

Bond-Lamberty, B., Rocha, A. V., Calvin, K., Holmes, B., Wang, C., and Goulden, M. L.: Disturbance legacies and climate jointly drive tree growth and mortality in an intensively studied boreal forest, Glob. Change Biol., 20, 216-227, https://doi.org/10.1111/gcb.12404, 2013.

Bonfils, C. J. W., Phillips, T. J., Lawrence, D. M., Cameron-Smith, P., Riley, W. J., and Subin, Z. M.: On the influence of shrub height and expansion on northern high latitude climate, Environ. Res. Lett., 7, 015503, https://doi.org/10.1088/1748-9326/7/1/015503, 2012.

Bret-Harte, M. S., Mack, M. C., Shaver, G. R., Huebner, D. C., Johnston, M., Mojica, C. A., Pizano, C., and Reiskind, J. A.: The response of Arctic vegetation and soils following an unusually severe tundra fire, Philos. T. Roy. Soc. B, 368, 20120490-20120490, https://doi.org/10.1111/j.13652745.2008.01378.x, 2013.

Briggs, M. A., Walvoord, M. A., and McKenzie, J. M.: New permafrost is forming around shrinking Arctic lakes, but will it last?, Geophys. Res. Lett., 41, 1585-1592, https://doi.org/10.1002/2014g1059251, 2014.

Brown, D., Jorgenson, M. T., Douglas, T. A., Romanovsky, V. E., Kielland, K., Hiemstra, C. A., Euskirchen, E. S., and Ruess, R. W.: Interactive effects of wildfire and climate on permafrost degradation in Alaskan lowland forests, J. Geophys. Res.-Biogeo., 120, 1619-1637, https://doi.org/10.1002/2015jg003033, 2015.

Brown, J., Ferrians, O. J., Heginbottom, J. A., and Melinikov, E. S.: Circum-arctic map of permafrost and ground ice conditions, available at: https://nsidc.org/data/ggd318 (last access: $29 \mathrm{Au}$ gust 2018), 1998.

Bunn, A. G. and Goetz, S. J.: Trends in satellite-observed circumpolar photosynthetic activity from 1982 to 2003: The influence of seasonality, cover type, and vegetation density, Earth Interact., 10, 1-19, 2006.

Burn, C. R.: The response (1958-1997) of permafrost and nearsurface ground temperatures to forest fire, Takhini River valley, southern Yukon Territory, Can. J. Earth Sci., 35, 184-199, https://doi.org/10.1139/e97-105, 1998.

Cable, W. L., Romanovsky, V. E., and Jorgenson, M. T.: Scalingup permafrost thermal measurements in western Alaska using an ecotype approach, The Cryosphere, 10, 2517-2532, https://doi.org/10.5194/tc-10-2517-2016, 2016. 
Chapin III, F. S., Eugster, W., McFadden, J., Lynch, A., and Walker, D.: Summer differences among arctic ecosystems in regional climate forcing, J. Climate, 13, 2002-2010, 2000a.

Chapin III, F. S., McGuire, A., Randerson, J., Pielke, R., Baldocchi, D., Hobbie, S., Roulet, N., Eugster, W., Kasischke, E., and Rastetter, E.: Arctic and boreal ecosystems of western North America as components of the climate system, Glob. Change Biol., 6, 211-223, 2000b.

Chapin III, F. S., Sturm, M., Serreze, M. C., McFadden, J. P., Key, J. R., Lloyd, A. H., McGuire, A. D., Rupp, T. S., Lynch, A. H., Schimel, J. P., Beringer, J., Chapman, W. L., Epstein, H. E., Euskirchen, E. S., Hinzman, L. D., Jia, G., Ping, C.-L., Tape, K. D., Thompson, C. D. C., Walker, D. A., and Welker, J. M.: Role of land-surface changes in Arctic summer warming, Science, 310, 657-660, https://doi.org/10.1126/science.1117368, 2005.

Christiansen, C. T., Mack, M. C., DeMarco, J., and Grogan, P.: Decomposition of Senesced Leaf Litter is Faster in Tall Compared to Low Birch Shrub Tundra, Ecosystems, 170, 809-816, https://doi.org/10.1007/s10021-018-0240-6, 2018.

Commane, R., Lindaas, J., Benmergui, J., Luus, K. A., Chang, R. Y. W., Daube, B. C., Euskirchen, E. S., Henderson, J. M., Karion, A., Miller, J. B., Miller, S. M., Parazoo, N. C., Randerson, J. T., Sweeney, C., Tans, P., Thoning, K., Veraverbeke, S., Miller, C. E., and Wofsy, S. C.: Carbon dioxide sources from Alaska driven by increasing early winter respiration from Arctic tundra, P. Natl. Acad. Sci. USA, 114, 5361-5366, https://doi.org/10.1073/pnas.1618567114, 2017.

Comyn-Platt, E., Hayman, G., huntingford, C., Chadburn, S. E., Burke, E. J., Harper, A. B., Collins, W. J., Webber, C. P., Powell, T., Cox, P. M., Gedney, N., and Sitch, S.: Carbon budgets for 1.5 and $2{ }^{\circ} \mathrm{C}$ targets lowered by natural wetland and permafrost feedbacks, Nat. Geosci., 11, 568-573, https://doi.org/10.1038/s41561-018-0174-9, 2018.

Cornelissen, J. H., Van Bodegom, P. M., Aerts, R., Callaghan, T. V., Van Logtestijn, R. S., Alatalo, J., Stuart Chapin, F., Gerdol, R., Gudmundsson, J., Gwynn-Jones, D., Hartley, A. E., Hik, D. S., Hofgaard, A., Jónsdóttir, I. S., Karlsson, S., Klein, J. A., Laundre, J., Magnusson, B., Michelsen, A., Molau, U., Onipchenko, V. G., Quested, H. M., Sandvik, S. M., Schmidt, I. K., Shaver, G. R., Solheim, B., Soudzilovskaia, N. A., Stenström, A., Tolvanen, A., Totland, Ø., Wada, N., Welker, J. M., and Zhao, X.: Global negative vegetation feedback to climate warming responses of leaf litter decomposition rates in cold biomes, Ecol. Lett., 10, 619627, https://doi.org/10.1111/j.1461-0248.2007.01051.x, 2007.

Crampton, C. B.: A study of the dynamics of hummocky microrelief in the Canadian north, Can. J. Earth Sci., 14, 639-649, 1977.

Curasi, S. R., Loranty, M. M., and Natali, S. M.: Water track distribution and effects on carbon dioxide flux in an eastern Siberian upland tundra landscape, Environ. Res. Lett., 11, 1-12, https://doi.org/10.1088/1748-9326/11/4/045002, 2016.

de Grandpré, I., Fortier, D., and Stephani, E.: Degradation of permafrost beneath a road embankment enhanced by heat advected in groundwater, Can. J. Earth Sci., 49, 953-962, https://doi.org/10.1016/0148-9062(79)90657-0, 2012.

Domine, F., Barrere, M., Sarrazin, D., Morin, S., and Arnaud, L.: Automatic monitoring of the effective thermal conductivity of snow in a low-Arctic shrub tundra, The Cryosphere, 9, 12651276, https://doi.org/10.5194/tc-9-1265-2015, 2015.
Douglas, T. A., Jones, M. C., Hiemstra, C. A., and Arnold, J. R.: Sources and sinks of carbon in boreal ecosystems of interior Alaska: A review, Elem. Sci. Anth., 2, 000032, https://doi.org/10.12952/journal.elementa.000032, 2014.

Douglas, T. A., Jorgenson, M. T., Brown, D. R. N., Campbell, S. W., Hiemstra, C. A., Saari, S. P., Bjella, K., and Liljedahl, A. K.: Degrading permafrost mapped with electrical resistivity tomography, airborne imagery and LiDAR, and seasonal thaw measurements, Geophysics, 81, WA71-WA85, https://doi.org/10.1190/geo2015-0149.1, 2016.

Eaton, A. K., Rouse, W. R., Lafleur, P. M., Marsh, P., and Blanken, P. D.: Surface Energy Balance of the Western and Central Canadian Subarctic: Variations in the Energy Balance among Five Major Terrain Types, J. Climate, 14, 3692-3703, https://doi.org/10.1175/15200442(2001)014<3692:sebotw>2.0.co;2, 2001.

Elmendorf, S. C., Henry, G. H. R., Hollister, R. D., Björk, R. G., Bjorkman, A. D., Callaghan, T. V., Collier, L. S., Cooper, E. J., Cornelissen, J. H. C., Day, T. A., Fosaa, A. M., Gould, W. A., Grétarsdóttir, J., Harte, J., Hermanutz, L., Hik, D. S., Hofgaard, A., Jarrad, F., Jónsdóttir, I. S., Keuper, F., Klanderud, K., Klein, J. A., Koh, S., Kudo, G., Lang, S. I., Loewen, V., May, J. L., Mercado, J., Michelsen, A., Molau, U., Myers-Smith, I. H., Oberbauer, S. F., Pieper, S., Post, E., Rixen, C., Robinson, C. H., Schmidt, N. M., Shaver, G. R., Stenström, A., Tolvanen, A., Totland, Ø., Troxler, T., Wahren, C.-H., Webber, P. J., Welker, J. M., and Wookey, P. A.: Global assessment of experimental climate warming on tundra vegetation: heterogeneity over space and time, Ecol. Lett., 15, 164-175, https://doi.org/10.1111/j.14610248.2011.01716.x, 2012a.

Elmendorf, S. C., Henry, G. H. R., Hollister, R. D., Björk, R. G., Boulanger-Lapointe, N., Cooper, E. J., Cornelissen, J. H. C., Day, T. A., Dorrepaal, E., Elumeeva, T. G., Gill, M., Gould, W. A., Harte, J., Hik, D. S., Hofgaard, A., Johnson, D. R., Johnstone, J. F., Jónsdóttir, I. S., Jorgenson, J. C., Klanderud, K., Klein, J. A., Koh, S., Kudo, G., Lara, M., Lévesque, E., Magnusson, B., May, J. L., Mercado-Dýìaz, J. A., Michelsen, A., Molau, U., Myers-Smith, I. H., Oberbauer, S. F., Onipchenko, V. G., Rixen, C., Schmidt, N. M., Shaver, G. R., Spasojevic, M. J., Pórhallsdóttir, P. E., Tolvanen, A., Troxler, T., Tweedie, C. E., Villareal, S., Wahren, C.-H., Walker, X., Webber, P. J., Welker, J. M., and Wipf, S.: Plot-scale evidence of tundra vegetation change and links to recent summer warming, Nat. Clim. Change, 2, 1-5, https://doi.org/10.1038/nclimate1465, 2012b.

Essery, R. and Pomeroy, J.: Vegetation and topographic control of wind-blown snow distributions in distributed and aggregated simulations for an Arctic tundra basin, J. Hydrometeorol., 5, 735-744, https://doi.org/10.1175/15257541(2004)005<0735:vatcow>2.0.co;2, 2004.

Eugster, W., Rouse, W., Pielke, R., Sr, Joseph, P., Mcfadden, D., Baldocchi, T., Kittel, F., Chapin, S., Liston, G. E., Vidale, P. L., Vaganov, E., and Chambers, S.: Land-atmosphere energy exchange in Arctic tundra and boreal forest: available data and feedbacks to climate, Glob. Change Biol., 6, 84-115, 2000.

Fan, Z., Neff, J. C., Harden, J. W., Zhang, T., Veldhuis, H., Czimczik, C. I., Winston, G. C., and O'Donnell, J. A.: Water and heat transport in boreal soils: Implications for soil response to climate change, Sci. Total Environ., 409, 1836-1842, https://doi.org/10.1016/j.scitotenv.2011.02.009, 2011. 
Fauria, M. M., Helle, T., and Niva, A.: Removal of the lichen mat by reindeer enhances tree growth in a northern Scots pine forest, Can. J. Forest Res., 38, 2981-2993, 2008.

Fedorov, A. N., Iwahana, G., Konstantinov, P. Y., Machimura, T., Argunov, R. N., Efremov, P. V., Lopez, L. M. C., and Takakai, F.: Variability of Permafrost and Landscape Conditions Following Clear Cutting of Larch Forest in Central Yakutia, Permafrost Periglac., 28, 331-338, https://doi.org/10.1002/ppp.1897, 2016.

Filhol, S. and Sturm, M.: Snow bedforms: A review, new data, and a formation model, J. Geophys. Res.-Earth, 120, 1645-1669, https://doi.org/10.1002/2015jf003529, 2015.

Fisher, J. P., Estop Aragonés, C., Thierry, A., Charman, D. J., Wolfe, S. A., Hartley, I. P., Murton, J. B., Williams, M., and Phoenix, G. K.: The influence of vegetation and soil characteristics on activelayer thickness of permafrost soils in boreal forest, Glob. Change Biol., 22, 3127-3140, https://doi.org/10.1111/gcb.13248, 2016.

Forbes, B. C.: Aspects of natural recovery of soils, hydrology and vegetation at an abandoned high arctic settlement, Baffin Island, Canada, Proceedings of the Sixth International Conference on Permafrost, 1, 176-181, 1993.

Forbes, B. C.: Tundra disturbance studies, III: Short-term effects of Aeolian sand and dust, Yamal Region, Northwest Siberia, Environ. Conserv., 22, 335-344, 1995.

Forbes, B. C.: Cumulative impacts of vehicle traffic on high arctic tundra: soil temperature, plant biomass, species richness and mineral nutrition, Yellowknife, Proceedings of the Seventh International Conference on permafrost, CA, 1998.

Forbes, B. C. and Kumpula, T.: The Ecological Role and Geography of Reindeer (Rangifer tarandus) in Northern Eurasia, Geography Compass, 3, 1356-1380, https://doi.org/10.1111/j.17498198.2009.00250.x, 2009.

Forbes, B. C., Ebersole, J. J., and Strandberg, B.: Anthropogenic disturbance and patch dynamics in circumpolar arctic ecosystems, Conserv. Biol., 15, 954-969, https://doi.org/10.1046/j.1523-1739.2001.015004954.x, 2001.

Forbes, B. C., Fauria, M. M., and Zetterberg, P.: Russian Arctic warming and "greening" are closely tracked by tundra shrub willows, Glob. Change Biol., 16, 1542-1554, https://doi.org/10.1111/j.1365-2486.2009.02047.x, 2010.

Forkel, M., Carvalhais, N., Roedenbeck, C., Keeling, R., Heimann, M., Thonicke, K., Zaehle, S., and Reichstein, M.: Enhanced seasonal $\mathrm{CO}_{2}$ exchange caused by amplified plant productivity in northern ecosystems, Science, 351, 696-699, https://doi.org/10.1126/science.aac4971, 2016.

Francis, J. A., White, D. M., Cassano, J. J., Gutowski, W. J., Hinzman, L. D., Holland, M. M., Steele, M. A., and Vörösmarty, C. J.: An arctic hydrologic system in transition: Feedbacks and impacts on terrestrial, marine, and human life, J. Geophys. Res., 114, G04019, https://doi.org/10.1029/2008JG000902, 2009.

French, N. H., Whitley, M. A., and Jenkins, L. K.: Fire disturbance effects on land surface albedo in Alaskan tundra, J. Geophys. Res.-Biogeo., 121, 841-854, https://doi.org/10.1002/2015jg003177, 2016.

Froese, D. G., Westgate, J. A., Reyes, A. V., Enkin, R. J., and Preece, S. J.: Ancient Permafrost and a Future, Warmer Arctic, Science, 321, 1648-1648, https://doi.org/10.1126/science.1157525, 2008.

Frolking, S., Roulet, N., and Fuglestvedt, J.: How northern peatlands influence the Earth's radiative budget: Sustained methane emission versus sustained carbon sequestration, J. Geophys. Res., 111, G01008, https://doi.org/10.1029/2005JG000091, 2006.

Frost, G. V. and Epstein, H. E.: Tall shrub and tree expansion in Siberian tundra ecotones since the 1960s, Glob. Change Biol., 20, 1264-1277, https://doi.org/10.1111/gcb.12406, 2014.

Furayev, V., Vaganov, E. A., Tchebakova, N. M., and Valendik, E. N.: Effects of Fire and Climate on Successions and Structural Changes in The Siberian Boreal Forest, Eurasian Journal of Forest Research, 2, 1-15, 2001.

Gamon, J. A., Kershaw, G. P., Williamson, S., and Hik, D. S.: Microtopographic patterns in an arctic baydjarakh field: do finegrain patterns enforce landscape stability?, Environ. Res. Lett., 7, 015502, https://doi.org/10.1088/1748-9326/7/1/015502, 2012.

Genet, H., Mcguire, A. D., Barrett, K., Breen, A., Euskirchen, E. S., Johnstone, J. F., Kasischke, E. S., Melvin, A. M., Bennett, A., Mack, M. C., Rupp, T. S., Schuur, A. E. G., Turetsky, M. R., and Yuan, F.: Modeling the effects of fire severity and climate warming on active layer thickness and soil carbon storage of black spruce forests across the landscape in interior Alaska, Environ. Res. Lett., 8, 045016, https://doi.org/10.1088/17489326/8/4/045016, 2013.

Gill, H. K., Lantz, T. C., O’Neill, B., and Kokelj, S. V.: Cumulative Impacts and Feedbacks of a Gravel Road on Shrub Tundra Ecosystems in the Peel Plateau, Northwest Territories, Canada, Arct. Antarct. Alp. Res., 46, 947-961, https://doi.org/10.1657/1938-4246-46.4.947, 2014.

Goodrich, L. E.: The influence of snow cover on the ground thermal regime, Can. Geotech. J., 19, 421-432, https://doi.org/10.1139/t82-047, 1982.

Gouttevin, I., Ménégoz, M., Domine, F., Krinner, G., Koven, C., Ciais, P., Tarnocai, C., and Boike, J.: How the insulating properties of snow affect soil carbon distribution in the continental pan-Arctic area, J. Geophys. Res., 117, G02020, https://doi.org/10.1029/2011JG001916, 2012.

Göckede, M., Kittler, F., Kwon, M. J., Burjack, I., Heimann, M., Kolle, O., Zimov, N., and Zimov, S.: Shifted energy fluxes, increased Bowen ratios, and reduced thaw depths linked with drainage-induced changes in permafrost ecosystem structure, The Cryosphere, 11, 2975-2996, https://doi.org/10.5194/tc-112975-2017, 2017.

Graven, H. D., Keeling, R. F., Piper, S. C., Patra, P. K., Stephens, B. B., Wofsy, S. C., Welp, L. R., Sweeney, C., Tans, P. P., Kelley, J. J., Daube, B. C., Kort, E. A., Santoni, G. W., and Bent, J. D.: Enhanced Seasonal Exchange of $\mathrm{CO}_{2}$ by Northern Ecosystems Since 1960, Science, 341, 1085-1089, https://doi.org/10.1126/science.1239207, 2013.

Guay, K. C., Beck, P. S. A., Berner, L. T., Goetz, S. J., Baccini, A., and Buermann, W.: Vegetation productivity patterns at high northern latitudes: a multi-sensor satellite data assessment, Glob. Change Biol., 20, 3147-3158, https://doi.org/10.1111/gcb.12647, 2014.

Halsey, L. A., Vitt, D. H., and Zoltai, S. C.: Disequilibrium response of permafrost in boreal continental western Canada to climate change, Climatic Change, 30, 57-73, https://doi.org/10.1007/BF01093225, 1995.

Harden, J. W., Trumbore, S. E., Stocks, B. J., Hirsch, A., Gower, S. T., O'neill, K. P., and Kasischke, E. S.: The role of fire 
in the boreal carbon budget, Glob. Change Biol., 6, 174-184, https://doi.org/10.1046/j.1365-2486.2000.06019.x, 2000.

Harms, T. K., Abbott, B. W., and Jones, J. B.: Thermo-erosion gullies increase nitrogen available for hydrologic export, Biogeochemistry, 117, 299-311, https://doi.org/10.1007/s10533-0139862-0, 2014.

Hayes, D. J., Mcguire, A. D., Kicklighter, D. W., Gurney, K. R., Burnside, T. J., and Melillo, J. M.: Is the northern high-latitude land-based $\mathrm{CO}_{2}$ sink weakening?, 25, GB3018, https://doi.org/10.1029/2010GB003813, 2011.

Heijmans, M. M. P. D., Arp, W. J., and Chapin III, F. S.: Carbon dioxide and water vapour exchange from understory species in boreal forest, Agr. Forest Meteorol., 123, 135-147, https://doi.org/10.1016/j.agrformet.2003.12.006, 2004a.

Heijmans, M. M. P. D., Arp, W. J., and Chapin, F. S.: Controls on moss evaporation in a boreal black spruce forest, Global Biogeochem. Cy., 18, GB2004, https://doi.org/10.1029/2003GB002128, 2004b.

Helbig, M., Pappas, C., and Sonnentag, O.: Permafrost thaw and wildfire: Equally important drivers of boreal tree cover changes in the Taiga Plains, Canada, Geophys. Res. Lett., 43, 1598-1606, https://doi.org/10.1002/2015GL067193, 2016a.

Helbig, M., Wischnewski, K., Kljun, N., Chasmer, L. E., Quinton, W. L., Detto, M., and Sonnentag, O.: Regional atmospheric cooling and wetting effect of permafrost thawinduced boreal forest loss, Glob. Change Biol., 22, 4048-4066, https://doi.org/10.1111/gcb.13348, 2016b.

Higgins, K. L. and Garon-Labrecque, M.-È.: Fine-scale influences on thaw depth in a forested peat plateau landscape in the Northwest Territories, Canada: Vegetation trumps microtopography, Permafrost Periglac., 29, 60-70, https://doi.org/10.1002/ppp.1961, 2018.

Hinkel, K. M. and Nelson, F. E.: Spatial and temporal patterns of active layer thickness at Circumpolar Active Layer Monitoring (CALM) sites in northern Alaska, 1995-2000, J. Geophys. Res., 108, 8168, https://doi.org/10.1029/2001jd000927, 2003.

Hinkel, K. M. and Outcalt, S. I.: Identification of heattransfer processes during soil cooling, freezing, and thaw in central Alaska, Permafrost Periglac., 5, 217-235, https://doi.org/10.1002/ppp.3430050403, 1994.

Hinkel, K. M., Paetzold, F., Nelson, F. E., and Bockheim, J. G.: Patterns of soil temperature and moisture in the active layer and upper permafrost at Barrow, Alaska: 1993-1999, Global Planet. Change, 29, 293-309, 2001.

Hinzman, L. D., Kane, D. L., Gieck, R. E., and Everett, K. R.: Hydrologic and thermal properties of the active layer in the Alaskan Arctic, Cold Reg. Sci. Technol., 19, 95-110, https://doi.org/10.1016/0165-232X(91)90001-W, 1991.

Hobbie, S.: Temperature and Plant Species Control Over Litter Decomposition in Alaskan Tundra, Ecol. Monogr., 66, 503-522, 1996.

Hobbie, S. E. and Gough, L.: Litter decomposition in moist acidic and non-acidic tundra with different glacial histories, Oecologia, 140, 113-124, https://doi.org/10.1007/s00442-004-1556-9, 2004.

Hu, F. S., Higuera, P. E., Walsh, J. E., Chapman, W. L., Duffy, P. A., Brubaker, L. B., and Chipman, M. L.: Tundra burning in Alaska: Linkages to climatic change and sea ice retreat, J. Geophys. Res., 115, G04002, https://doi.org/10.1029/2009JG001270, 2010.
Huntington, H., Arnbom, T., Danielson, F., Enghoff, M., Euskirchen, E., Forbes, B., Kurvits, T., Levermann, N., Lovstrom, P., Mustonen, K., Mustonen, T., Schiots, M., Sommerkorn, M., Svoboda, M., Topp-Jorgenson, E., and York, G.: Disturbance, feedbacks and conservation, in Arctic Biodiversity Assessment Status and trends in Arctic biodiversity, Akureyri: Conservation of Arctic Flora and Fauna, available at: https://oaarchive.arctic-council.org/handle/11374/223 (last access: 30 August 2018), 2013.

Iijima, Y., Fedorov, A. N., Park, H., Suzuki, K., Yabuki, H., Maximov, T. C., and Ohata, T.: Abrupt increases in soil temperatures following increased precipitation in a permafrost region, central Lena River basin, Russia, Permafrost Periglac., 21, 30-41, https://doi.org/10.1002/ppp.662, 2010.

Iijima, Y., Ohta, T., Kotani, A., Fedorov, A. N., Kodama, Y., and Maximov, T. C.: Sap flow changes in relation to permafrost degradation under increasing precipitation in an eastern Siberian larch forest, Ecohydrology, 7, 177-187, https://doi.org/10.1002/eco.1366, 2014.

Iversen, C. M., Sloan, V. L., Sullivan, P. F., Euskirchen, E. S., Mcguire, A. D., Norby, R. J., Walker, A. P., Warren, J. M., and Wullschleger, S. D.: The unseen iceberg: plant roots in arctic tundra, New Phytol., 205, 34-58, https://doi.org/10.1111/nph.13003, 2015.

Iwahana, G., Machimura, T., and Kobayashi, Y.: Influence of forest clear-cutting on the thermal and hydrological regime of the active layer near Yakutsk, eastern Siberia, J. Geophys. Res.-Earth, 110, G02004, https://doi.org/10.1029/2005JG000039, 2005.

Jafarov, E. E., Romanovsky, V. E., Genet, H., David McGuire, A., and Marchenko, S. S.: The effects of fire on the thermal stability of permafrost in lowland and upland black spruce forests of interior Alaska in a changing climate, Environ. Res. Lett., 8, 035030, https://doi.org/10.1088/1748-9326/8/3/035030, 2013.

Jean, M. and Payette, S.: Dynamics of active layer in wooded palsas of northern Quebec, Geomorphology, 206, 87-96, https://doi.org/10.1016/j.geomorph.2013.10.001, 2014a.

Jean, M. and Payette, S.: Effect of Vegetation Cover on the Ground Thermal Regime of Wooded and NonWooded Palsas, Permafrost Periglac., 25, 281-294, https://doi.org/10.1002/ppp.1817, 2014b.

Jia, G., Epstein, H., and Walker, D.: Greening of arctic Alaska, 1981-2001, Geophys. Res. Lett., 30, 2067, https://doi.org/10.1029/2003GL018268, 2003.

Jiang, Y., Rocha, A. V., O’Donnell, J. A., Drysdale, J. A., Rastetter, E. B., Shaver, G. R., and Zhuang, Q.: Contrasting soil thermal responses to fire in Alaskan tundra and boreal forest, J. Geophys. Res.-Earth, 120, 363-378, https://doi.org/10.1002/2014jf003180, 2015.

Jin, Y., SCHAAF, C., Gao, F., Li, X., STRAHLER, A., Zeng, X., and Dickinson, R.: How does snow impact the albedo of vegetated land surfaces as analyzed with MODIS data?, Geophys. Res. Lett., 29, 12-11, 2002.

Jin, Y., Randerson, J. T., Goetz, S. J., Beck, P. S. A., Loranty, M. M., and Goulden, M. L.: The influence of burn severity on postfire vegetation recovery and albedo change during early succession in North American boreal forests, J. Geophys. Res., 117, G01036, https://doi.org/10.1029/2011JG001886, 2012.

Johansen, O.: Thermal conductivity of soils (No. CRREL-TL-637), Cold Regions Research and Engineering Lab Hanover NH, 1977. 
Johansson, T., Malmer, N., Crill, P. M., Friborg, T., ÅKERMAN, J. H., Mastepanov, M., and Christensen, T. R.: Decadal vegetation changes in a northern peatland, greenhouse gas fluxes and net radiative forcing, Glob. Change Biol., 12, 2352-2369, https://doi.org/10.1111/j.1365-2486.2006.01267.x, 2006.

Johnstone, J. F., Hollingsworth, T. N., Chapin III, F. S., and Mack, M. C.: Changes in fire regime break the legacy lock on successional trajectories in Alaskan boreal forest, Glob. Change Biol., 16, 1281-1295, https://doi.org/10.1111/j.13652486.2009.02051.x, 2010.

Jones, B. M., Kolden, C. A., Jandt, R., Abatzoglou, J. T., Urban, F., and Arp, C. D.: Fire Behavior, Weather, and Burn Severity of the 2007 Anaktuvuk River Tundra Fire, North Slope, Alaska, Arct. Antarct. Alp. Res., 41, 309-316, https://doi.org/10.1657/19384246-41.3.309, 2009.

Jones, B. M., Breen, A. L., Gaglioti, B. V., Mann, D. H., Rocha, A. V., Grosse, G., Arp, C. D., Kunz, M. L., and Walker, D. A.: Identification of unrecognized tundra fire events on the north slope of Alaska, J. Geophys. Res.-Biogeosci., 118, 1334-1344, https://doi.org/10.1002/jgrg.20113, 2013.

Jones, B. M., Grosse, G., Arp, C. D., Miller, E., Liu, L., Hayes, D. J., and Larsen, C. F.: Recent Arctic tundra fire initiates widespread thermokarst development, Scientific Reports, 5, 15865, https://doi.org/10.1038/srep15865, 2015.

Jones, M. C., Grosse, G., Jones, B. M., and Walter Anthony, K.: Peat accumulation in drained thermokarst lake basins in continuous, ice-rich permafrost, northern Seward Peninsula, Alaska, J. Geophys. Res., 117, G00M07, https://doi.org/10.1029/2011JG001766, 2012.

Jorgensen, C. J., Johansen, K. M. L., Westergaard-Nielsen, A., and Elberling, B.: Net regional methane sink in High Arctic soils of northeast Greenland, Nat. Geosci., 8, 20-23, https://doi.org/10.1038/NGEO2305, 2015.

Jorgenson, M. T. and Osterkamp, T. E.: Response of boreal ecosystems to varying modes of permafrost degradation, Can. J. Forest Res., 35, 2100-2111, https://doi.org/10.1139/x05-153, 2005.

Jorgenson, M. T., Racine, C. H., Walters, J. C., and Osterkamp, T. E.: Permafrost degradation and ecological changes associated with a warming climate in central Alaska, Climatic Change, 48, 551-579, 2001.

Jorgenson, M. T., Shur, Y. L., and Pullman, E. R.: Abrupt increase in permafrost degradation in Arctic Alaska, Geophys. Res. Lett., 33, L02503, https://doi.org/10.1029/2005GL024960, 2006.

Jorgenson, M. T., Romanovsky, V., Harden, J., Shur, Y., O’Donnell, J., Schuur, E. A. G., Kanevskiy, M., and Marchenko, S.: Resilience and vulnerability of permafrost to climate change, Can. J. Forest Res., 40, 1219-1236, 2010.

Jorgenson, M. T., HARDEN, J., and Kanevskiy, M.: Reorganization of vegetation, hydrology and soil carbon after permafrost degradation across heterogeneous boreal landscapes, Environ. Res. Lett., 8, 035017, https://doi.org/10.1088/1748-9326/8/3/035017, 2013.

Juday, G. P., Alix, C., and Grant III, T. A.: Spatial coherence and change of opposite white spruce temperature sensitivities on floodplains in Alaska confirms earlystage boreal biome shift, Forest Ecol. Manag., 350, 46-61, https://doi.org/10.1016/j.foreco.2015.04.016, 2015.

Juszak, I., Erb, A. M., Maximov, T. C., and SchaepmanStrub, G.: Arctic shrub effects on NDVI, summer albedo and soil shading, Remote Sens. Environ., 153, 79-89, https://doi.org/10.1016/j.rse.2014.07.021, 2014.

Juszak, I., Eugster, W., Heijmans, M. M. P. D., and SchaepmanStrub, G.: Contrasting radiation and soil heat fluxes in Arctic shrub and wet sedge tundra, Biogeosciences, 13, 4049-4064, https://doi.org/10.5194/bg-13-4049-2016, 2016.

Kane, D. L., Hinzman, L. D., Benson, C. S., and Everett, K. R.: Hydrology of Imnavait Creek, an arctic watershed, Ecography, 12, 262-269, https://doi.org/10.1111/j.16000587.1989.tb00845.x, 1989.

Kane, D. L., Hinkel, K. M., Goering, D. J., Hinzman, L. D., and Outcalt, S. I.: Non-conductive heat transfer associated with frozen soils, Global Planet. Change, 29, 275-292, 2001.

Kane, E. S., Kasischke, E. S., Valentine, D. W., Turetsky, M. R., and Mcguire, A. D.: Topographic influences on wildfire consumption of soil organic carbon in interior Alaska: Implications for black carbon accumulation, J. Geophys. Res., 112, G03017, https://doi.org/10.1029/2007JG000458, 2007.

Kasischke, E. and Johnstone, J.: Variation in postfire organic layer thickness in a black spruce forest complex in interior Alaska and its effects on soil temperature and moisture, Can. J. For. Res., 35, 2164-2177, 2005.

Kasischke, E. and Turetsky, M.: Recent changes in the fire regime across the North American boreal region-spatial and temporal patterns of burning across Canada and Alaska, Geophys. Res. Lett., 33, L09703, https://doi.org/10.1029/2006GL025677, 2006.

Kasurinen, V., Alfredsen, K., Kolari, P., Mammarella, I., Alekseychik, P., Rinne, J., Vesala, T., Bernier, P., Boike, J., Langer, M., Belelli Marchesini, L., van Huissteden, K., Dolman, H., Sachs, T., Ohta, T., Varlagin, A., Rocha, A., Arain, A., Oechel, W., Lund, M., Grelle, A., Lindroth, A., Black, A., Aurela, M., Laurila, T., Lohila, A., and Berninger, F.: Latent heat exchange in the boreal and arctic biomes, Glob. Change Biol., 20, 3439-3456, https://doi.org/10.1111/gcb.12640, 2014.

Kelly, R., Chipman, M. L., Higuera, P. E., Stefanova, I., Brubaker, L. B., and Hu, F. S.: Recent burning of boreal forests exceeds fire regime limits of the past 10,000 years, P. Natl. Acad. Sci. USA, 110, 13055-13060, https://doi.org/10.1073/pnas.1305069110, 2013.

Kershaw, G. P.: Some abiotic consequences of the CANOL Crude Oil Pipeline Project, 35 years after abandonment, Proceedings of the Fourth International Conference on Permafrost, 595-600, 1983.

Kershaw, G. P.: Snowpack Characteristics Following Wildfire on a Simulated Transport Corridor and Adjacent Subarctic Forest, Tulita, N.W.T., Canada, Arct. Antarct. Alp. Res., 33, 131-139, https://doi.org/10.2307/1552213, 2001.

Kershaw, G. P. and McCulloch, J.: Midwinter Snowpack Variation Across the Arctic Treeline, Churchill, Manitoba, Canada, Arct. Antarct. Alp. Res., 39, 9-15, https://doi.org/10.1657/15230430(2007)39[9:msvata]2.0.co;2, 2007.

Keuper, F., Bodegom, P. M., Dorrepaal, E., Weedon, J. T., Hal, J., Logtestijn, R. S. P., and Aerts, R.: A frozen feast: thawing permafrost increases plant-available nitrogen in subarctic peatlands, Glob. Change Biol., 18, 1998-2007, https://doi.org/10.1111/j.1365-2486.2012.02663.x, 2012.

Kharuk, V. I., Ranson, K. J., and Dvinskaya, M. L.: Wildfires dynamic in the larch dominance zone, Geophys. Res. Lett., 35, L01402, https://doi.org/10.1029/2007GL032291, 2008. 
Kharuk, V. I., Dvinskaya, M. L., and Ranson, K. J.: Fire return intervals within the northern boundary of the larch forest in Central Siberia, Int. J. Wildland Fire, 22, 207-6, https://doi.org/10.1071/WF11181, 2013.

Kholodov, A., Gilichinsky, D., Ostroumov, V., Sorokovikov, V. A., Abramov, A. A., Davydov, S., and Romanovsky, V.: Regional and local variability of modern natural changes in permafrost temperature in the Yakutian coastal lowlands, Northeastern Siberia, Proceedings of the Tenth International Conference on Permafrost, 2012

Kling, G. W., Kipphut, G. W., and Miller, M. C.: Arctic lakes and streams as gas conduits to the atmosphere: implications for tundra carbon budgets, Science, 251, 298-301, 1991.

Kokelj, S. V. and Jorgenson, M. T.: Advances in Thermokarst Research, Permafrost Periglac., 24, 108-119, https://doi.org/10.1002/ppp.1779, 2013.

Koven, C. D., Ringeval, B., Friedlingstein, P., Ciais, P., Cadule, P., Khvorostyanov, D., Krinner, G., and Tarnocai, C.: Permafrost carbon-climate feedbacks accelerate global warming, P. Natl. Acad. Sci., 108, 14769-14774, https://doi.org/10.1073/pnas.1103910108, 2011.

Kropp, H., Loranty, M., Alexander, H. D., Berner, L. T., Natali, S. M., and Spawn, S. A.: Environmental constraints on transpiration and stomatal conductance in a Siberian Arctic boreal forest, J. Geophys. Res.-Biogeo., 122, 487-497, https://doi.org/10.1002/2016JG003709, 2017.

Kukavskaya, E. A., Soja, A. J., Petkov, A. P., Ponomarev, E. I., Ivanova, G. A., and Conard, S. G.: Fire emissions estimates in Siberia: evaluation of uncertainties in area burned, land cover, and fuel consumption, Can. J. Forest Res., 43, 493-506, https://doi.org/10.1139/cjfr-2012-0367, 2012.

Landhäusser, S. M., and Wein, R. W.: Postfire Vegetation Recovery and Tree Establishment at the Arctic Treeline: ClimateChange-Vegetation-Response Hypotheses, J. Ecol., 81, 665-672, https://doi.org/10.2307/2261664, 1993.

Langer, M., Westermann, S., Muster, S., Piel, K., and Boike, J.: The surface energy balance of a polygonal tundra site in northern Siberia - Part 2: Winter, The Cryosphere, 5, 509-524, https://doi.org/10.5194/tc-5-509-2011, 2011a.

Langer, M., Westermann, S., Muster, S., Piel, K., and Boike, J.: The surface energy balance of a polygonal tundra site in northern Siberia - Part 1: Spring to fall, The Cryosphere, 5, 151-171, https://doi.org/10.5194/tc-5-151-2011, 2011b.

Lantz, T. C. and Kokelj, S. V.: Increasing rates of retrogressive thaw slump activity in the Mackenzie Delta region, N.W.T., Canada, Geophys. Res. Lett., 35, L06502, https://doi.org/10.1029/2007GL032433, 2008.

Lantz, T. C., Marsh, P., and Kokelj, S. V.: Recent shrub proliferation in the Mackenzie Delta uplands and microclimatic implications, Ecosystems, 16, 47-59, https://doi.org/10.1007/s10021012-9595-2, 2013.

Lara, M. J., Genet, H., McGuire, A. D., Euskirchen, E. S., Zhang, Y., Brown, D. R. N., Jorgenson, M. T., Romanovsky, V., Breen, A., and Bolton, W. R.: Thermokarst rates intensify due to climate change and forest fragmentation in an Alaskan boreal forest lowland, Glob. Change Biol., 22, 816-829, https://doi.org/10.1111/gcb.13124, 2016.

Lawrence, D. M. and Swenson, S. C.: Permafrost response to increasing Arctic shrub abundance depends on the rela- tive influence of shrubs on local soil cooling versus largescale climate warming, Environ. Res. Lett., 6, 045504, https://doi.org/10.1088/1748-9326/6/4/045504, 2011.

Lee, X., Goulden, M. L., Hollinger, D. Y., Barr, A., and Black, T. A.: Observed increase in local cooling effect of deforestation at higher latitudes, Nature, 479, 384-387, https://doi.org/10.1038/nature10588, 2011.

Leibman, M., Khomutov, A., and Kizyakov, A.: Cryogenic landslides in the West-Siberian plain of Russia: classification, mechanisms, and landforms, in Landslides in Cold Regions in the Context of Climate Change, edited by: Shan, W., Guo, Y., Mauri, H., and Strom, A., Springer, 143-162, 2014

Li, Y., Zhao, M., Motesharrei, S., Mu, Q., Kalnay, E., and $\mathrm{Li}, \mathrm{S}$.: Local cooling and warming effects of forests based on satellite observations, Nat. Commun., 6, 1-8, https://doi.org/10.1038/ncomms7603, 2015.

Liljedahl, A., Hinzman, L., Busey, R., and Yoshikawa, K.: Physical short-term changes after a tussock tundra fire, Seward Peninsula, Alaska, J. Geophys. Res., 112, F02S07, https://doi.org/10.1029/2006JF000554, 2007.

Liljedahl, A. K., Boike, J., Daanen, R. P., Fedorov, A. N., Frost, G. V., Grosse, G., Hinzman, L. D., Iijma, Y., Jorgenson, J. C., Matveyeva, N., Necsoiu, M., Raynolds, M. K., Romanovsky, V. E., Schulla, J., Tape, K. D., Walker, D. A., Wilson, C. J., Yabuki, H., and Zona, D.: Pan-Arctic ice-wedge degradation in warming permafrost and its influence on tundra hydrology, Nat. Geosci., 9, 312-318, https://doi.org/10.1038/ngeo2674, 2016.

Liston, G. E., McFadden, J., Sturm, M., and Pielke, R.: Modelled changes in arctic tundra snow, energy and moisture fluxes due to increased shrubs, Glob. Change Biol., 8, 17-32, 2002.

Lloyd, A. H., Bunn, A. G., and Berner, L.: A latitudinal gradient in tree growth response to climate warming in the Siberian taiga, Glob. Change Biol., 17, 1935-1945, https://doi.org/10.1111/j.1365-2486.2010.02360.x, 2010.

Lopez C, M. L., Saito, H., Kobayashi, Y., Shirota, T., Iwahana, G., Maximov, T. C., and Fukuda, M.: Interannual environmental-soil thawing rate variation and its control on transpiration from Larix cajanderi, Central Yakutia, Eastern Siberia, J. Hydrol., 338, 251260, https://doi.org/10.1016/j.jhydrol.2007.02.039, 2007.

Loranty, M. and Alexander, H. D.: RUI: Collaborative Research: Fire regime influences on carbon dynamics of Siberian boreal forests, Arctic Data Center, https://doi.org/10.18739/A2CD3V, 2014.

Loranty, M. M., Goetz, S. J., and Beck, P. S. A.: Tundra vegetation effects on pan-Arctic albedo, Environ. Res. Lett., 6, 024014, https://doi.org/10.1088/1748-9326/6/2/024014, 2011.

Loranty, M. M., Berner, L. T., Goetz, S. J., Jin, Y., and Randerson, J. T.: Vegetation controls on northern high latitude snow-albedo feedback: observations and CMIP5 model simulations, Glob. Change Biol., 20, 594-606, https://doi.org/10.1111/gcb.12391, 2014a.

Loranty, M. M., Natali, S. M., Berner, L. T., Goetz, S. J., Holmes, R. M., Davydov, S. P., Zimov, N. S., and Zimov, S. A.: Siberian tundra ecosystem vegetation and carbon stocks four decades after wildfire, J. Geophys. Res.-Biogeo., 119, 2144 2154, https://doi.org/10.1002/2014jg002730, 2014b.

Loranty, M. M., Liberman-Cribbin, W., Berner, L. T., Natali, S. M., Goetz, S. J., Alexander, H. D., and Kholodov, A. L.: Spatial variation in vegetation productivity trends, fire disturbance, and soil 
carbon across arctic-boreal permafrost ecosystems, Environ. Res. Lett., 11, 1-13, https://doi.org/10.1088/1748-9326/11/9/095008, 2016.

Loranty, M. M., Berner, L. T., Taber, E. D., Kropp, H., Natali, S. M., Alexander, H. D., Davydov, S. P., and Zimov, N. S.: Understory vegetation mediates permafrost active layer dynamics and carbon dioxide fluxes in open-canopy larch forests of northeastern Siberia, edited by: Rinnan, R., PLoS ONE, 13, e0194014, https://doi.org/10.1371/journal.pone.0194014, 2018.

Lynch, L. M., Machmuller, M. B., Cotrufo, M. F., Paul, E. A., and Wallenstein, M. D.: Tracking the fate of fresh carbon in the Arctic tundra: Will shrub expansion alter responses of soil organic matter to warming?, Soil Biol. Biochem., 120, 134-144, 2018.

Lyons, E. A., Jin, Y., and Randerson, J. T.: Changes in surface albedo after fire in boreal forest ecosystems of interior Alaska assessed using MODIS satellite observations, J. Geophys. Res., 113, 1-15, https://doi.org/10.1029/2007JG000606, 2008.

Macias-Fauria, M., Forbes, B. C., Zetterberg, P., and Kumpula, T.: Eurasian Arctic greening reveals teleconnections and the potential for structurally novel ecosystems, Nat. Clim. Change, 2, 1-6, https://doi.org/10.1038/nclimate1558, 2012.

Mack, M. C., Treseder, K. K., Manies, K. L., Harden, J. W., Schuur, E. A. G., Vogel, J. G., Randerson, J. T., and Stuart Chapin, F.: Recovery of Aboveground Plant Biomass and Productivity After Fire in Mesic and Dry Black Spruce Forests of Interior Alaska, Ecosystems, 11, 209-225, https://doi.org/10.1007/s10021-0079117-9, 2008.

Mack, M. C., Bret-Harte, M. S., Hollingsworth, T. N., Jandt, R. R., Schuur, E. A. G., Shaver, G. R., and Verbyla, D. L.: Carbon loss from an unprecedented Arctic tundra wildfire, Nature, 475, 489492, https://doi.org/10.1038/nature10283, 2011.

Malhotra, A. and Roulet, N. T.: Environmental correlates of peatland carbon fluxes in a thawing landscape: do transitional thaw stages matter?, Biogeosciences, 12, 3119-3130, https://doi.org/10.5194/bg-12-3119-2015, 2015.

Malmer, N., Johansson, T., Olsrud, M., and Christensen, T. R.: Vegetation, climatic changes and net carbon sequestration in a North-Scandinavian subarctic mire over 30 years, Glob. Change Biol., 11, 1895-1909, https://doi.org/10.1111/j.13652486.2005.01042.x, 2005.

Mamet, S. D. and Kershaw, G. P.: Multi-scale Analysis of Environmental Conditions and Conifer Seedling Distribution Across the Treeline Ecotone of Northern Manitoba, Canada, Ecosystems, 16, 295-309, https://doi.org/10.1007/s10021-012-9614-3, 2013.

Mamet, S. D., Chun, K. P., Kershaw, G. G. L., Loranty, M. M., and Peter Kershaw, G.: Recent Increases in Permafrost Thaw Rates and Areal Loss of Palsas in the Western Northwest Territories, Canada, Permafrost Periglac., 28, 619-633, https://doi.org/10.1002/ppp.1951, 2017.

Marsh, P., Bartlett, P., MackKay, M., Pohl, S., and Lantz, T.: Snowmelt energetics at a shrub tundra site in the western Canadian Arctic, Hydrol. Process, 24, 3603-3620, https://doi.org/10.1002/hyp.7786, 2010.

Ménard, C. B., Essery, R., and Pomeroy, J.: Modelled sensitivity of the snow regime to topography, shrub fraction and shrub height, Hydrol. Earth Syst. Sci., 18, 2375-2392, https://doi.org/10.5194/hess-18-2375-2014, 2014.

Morse, P. D., Wolfe, S. A., Kokelj, S. V., and Gaanderse, A. J. R.: The Occurrence and Thermal Disequilibrium State of Per- mafrost in Forest Ecotopes of the Great Slave Region, Northwest Territories, Canada, Permafrost Periglac., 27, 145-162, https://doi.org/10.1002/ppp.1858, 2015.

Mu, C. C., Abbott, B. W., Zhao, Q., Su, H., Wang, S. F., Wu, Q. B., Zhang, T. J., and Wu, X. D.: Permafrost collapse shifts alpine tundra to a carbon source but reduces $\mathrm{N}_{2} \mathrm{O}$ and $\mathrm{CH}_{4}$ release on the northern Qinghai-Tibetan Plateau, Geophys. Res. Lett., 44, 8945-8952, https://doi.org/10.1002/2017GL074338, 2017.

Myers-Smith, I. H. and Hik, D. S.: Shrub canopies influence soil temperatures but not nutrient dynamics: An experimental test of tundra snow-shrub interactions, Ecol. Evol., 3, 3683-3700, https://doi.org/10.1002/ece3.710, 2013.

Myers-Smith, I. H., Arnesen, B. K., Thompson, R. M., and Chapin, F. S. I.: Cumulative impacts on Alaskan arctic tundra of a quarter century of road dust, Ecoscience, 13, 503-510, 2006.

Myers-Smith, I. H., Elmendorf, S. C., Beck, P. S. A., Wilmking, M., Hallinger, M., Blok, D., Tape, K. D., Rayback, S. A., Macias-Fauria, M., Forbes, B. C., Speed, J. D. M., BoulangerLapointe, N., Rixen, C., Lévesque, E., Schmidt, N. M., Baittinger, C., Trant, A. J., Hermanutz, L., Collier, L. S., Dawes, M. A., Lantz, T. C., Weijers, S., Jørgensen, R. H., Buchwal, A., Buras, A., Naito, A. T., Ravolainen, V., SchaepmanStrub, G., Wheeler, J. A., Wipf, S., Guay, K. C., Hik, D. S., and Vellend, M.: Climate sensitivity of shrub growth across the tundra biome, Nat. Clim. Change, 5, 887-891, https://doi.org/10.1038/nclimate2697, 2015.

Myneni, R., Keeling, C., Tucker, C., Asrar, G., and Nemani, R.: Increased plant growth in the northern high latitudes from 1981 to 1991, Nature, 386, 698-701, 1997.

Natali, S. M., Schuur, E. A. G., Trucco, C., Hicks Pries, C. E., Crummer, K. G., and Baron Lopez, A. F.: Effects of experimental warming of air, soil and permafrost on carbon balance in Alaskan tundra, Glob. Change Biol., 17, 1394-1407, https://doi.org/10.1111/j.1365-2486.2010.02303.x, 2011.

Natali, S. M., Schuur, E. A. G., Mauritz, M., Schade, J. D., Celis, G., Crummer, K. G., Johnston, C., Krapek, J., Pegoraro, E., Salmon, V. G., and Webb, E. E.: Permafrost thaw and soil moisture driving $\mathrm{CO}_{2}$ and $\mathrm{CH}_{4}$ release from upland tundra, J. Geophys. Res.-Biogeosci., 120, 525-537, https://doi.org/10.1002/2014jg002872, 2015.

Nauta, A. L., Heijmans, M. M. P. D., Blok, D., Limpens, J., Elberling, B., Gallagher, A., Li, B., Petrov, R. E., Maximov, T. C., van Huissteden, J., and Berendse, F.: Permafrost collapse after shrub removal shifts tundra ecosystem to a methane source, Nat. Clim. Change, 5, 67-70, https://doi.org/10.1038/nclimate2446, 2014.

Nauta, A. L., Heijmans, M. M. P. D., Blok, D., Limpens, J., Elberling, B., Gallagher, A., Li, B., Petrov, R. E., Maximov, T. C., van Huissteden, J., and Berendse, F.: Permafrost collapse after shrub removal shifts tundra ecosystem to a methane source, Nat. Clim. Change, 5, 67-70, https://doi.org/10.1038/nclimate2446, 2015.

Nossov, D. R., Torre Jorgenson, M., Kielland, K., and Kanevskiy, M. Z.: Edaphic and microclimatic controls over permafrost response to fire in interior Alaska, Environ. Res. Lett., 8, 035013, https://doi.org/10.1088/1748-9326/8/3/035013, 2013.

O’Donnell, J. A., Romanovsky, V. E., Harden, J. W., and Mcguire, A. D.: The Effect of Moisture Content on the Thermal Conductivity of Moss and Organic Soil Horizons From Black Spruce Ecosystems in Interior Alaska, Soil Science, 174, 646-651, https://doi.org/10.1097/ss.0b013e3181c4a7f8, 2009a. 
O’Donnell, J. A., Turetsky, M., Harden, J., Manies, K., Pruett, L., Shetler, G., and Neff, J.: Interactive Effects of Fire, Soil Climate, and Moss on $\mathrm{CO}_{2}$ Fluxes in Black Spruce Ecosystems of Interior Alaska, Ecosystems, 12, 57-72, 2009 b.

O'Donnell, J. A., Harden, J. W., McGuire, A. D., and Romanovsky, V. E.: Exploring the sensitivity of soil carbon dynamics to climate change, fire disturbance and permafrost thaw in a black spruce ecosystem, Biogeosciences, 8, 1367-1382, https://doi.org/10.5194/bg-8-1367-2011, 2011a.

O’Donnell, J. A., Harden, J. W., Mcguire, A. D., Kanevskiy, M. Z., Jorgenson, M. T., and Xu, X.: The effect of fire and permafrost interactions on soil carbon accumulation in an upland black spruce ecosystem of interior Alaska: implications for post-thaw carbon loss, Glob. Change Biol., 17, 1461-1474, https://doi.org/10.1111/j.1365-2486.2010.02358.x, 2011b.

O’Donnell, J. A., Jorgenson, M. T., Harden, J. W., Mcguire, A. D., Kanevskiy, M. Z., and Wickland, K. P.: The effects of permafrost thaw on soil hydrologic, thermal, and carbon dynamics in an Alaskan peatland, Ecosystems, 15, 213-229, https://doi.org/10.1007/s10021-011-9504-0, 2012.

Olefeldt, D., Turetsky, M. R., Crill, P. M., and Mcguire, A. D.: Environmental and physical controls on northern terrestrial methane emissions across permafrost zones, Glob. Change Biol., 19, 589603, https://doi.org/10.1111/gcb.12071, 2012.

Olefeldt, D., Goswami, S., Grosse, G., and Hayes, D.: Circumpolar distribution and carbon storage of thermokarst landscapes, Nature, 7, 13043, https://doi.org/10.1038/ncomms13043, 2016.

Olofsson, J.: Short- and long-term effects of changes in reindeer grazing pressure on tundra heath vegetation, J. Ecol., 94, 431440, https://doi.org/10.1111/j.1365-2745.2006.01100.x, 2006.

Olofsson, J., Kitti, H., Rautiainen, P., and Stark, S.: Effects of summer grazing by reindeer on composition of vegetation, productivity and nitrogen cycling, Ecography, 24, 13-24, https://doi.org/10.1034/j.1600-0587.2001.240103.x, 2001.

Olofsson, J., Hulme, P. E., Oksanen, L., and Suominen, O.: Importance of large and small mammalian herbivores for the plant community structure in the forest tundra ecotone, Oikos, 106, 324-334, https://doi.org/10.1111/j.00301299.2004.13224.x, 2004a.

Olofsson, J., Stark, S., and Oksanen, L.: Reindeer influence on ecosystem processes in the tundra, Oikos, 105, 386-396, https://doi.org/10.1111/j.0030-1299.2004.13048.x, 2004b.

Olofsson, J., Oksanen, L., Callaghan, T., Hulme, P. E., Oksanen, T., and Suominen, O.: Herbivores inhibit climate-driven shrub expansion on the tundra, Glob. Change Biol., 15, 2681-2693, https://doi.org/10.1111/j.1365-2486.2009.01935.x, 2009.

Osterkamp, T. E., Viereck, L., Shur, Y., Jorgenson, M. T., Racine, C., Doyle, A., and Boone, R. D.: Observations of thermokarst and its impact on boreal forests in Alaska, USA, Arct. Antarct. Alp. Res., 32, 303-315, 2000.

Osterkamp, T. E., Jorgenson, M. T., Schuur, E. A. G., Shur, Y. L., Kanevskiy, M. Z., Vogel, J. G., and Tumskoy, V. E.: Physical and ecological changes associated with warming permafrost and thermokarst in Interior Alaska, Permafrost Periglac., 20, 235256, https://doi.org/10.1002/ppp.656, 2009.

Outcalt, S. I., Nelson, F. E., and Hinkel, K. M.: The zerocurtain effect: Heat and mass transfer across an isothermal region in freezing soil, Water Resour. Res., 26, 1509-1516, https://doi.org/10.1029/wr026i007p01509, 1990.
Park, H., Walsh, J., Fedorov, A. N., Sherstiukov, A. B., Iijima, Y., and Ohata, T.: The influence of climate and hydrological variables on opposite anomaly in active-layer thickness between Eurasian and North American watersheds, The Cryosphere, 7, 631-645, https://doi.org/10.5194/tc-7-631-2013, 2013.

Pearson, R. G., Phillips, S. J., Loranty, M. M., Beck, P. S. A., Damoulas, T., Knight, S. J., and Goetz, S. J.: Shifts in Arctic vegetation and associated feedbacks under climate change, Nat. Clim. Change, 3, 673-677, https://doi.org/10.1038/nclimate1858, 2013.

Peng, C., Ma, Z., Lei, X., Zhu, Q., Chen, H., Wang, W., Liu, S., Li, W., Fang, X., and Zhou, X.: A drought-induced pervasive increase in tree mortality across Canada's boreal forests, Nat. Clim. Change, 1, 467-471, https://doi.org/10.1038/nclimate1293, 2011.

Phoenix, G. K. and Bjerke, J. W.: Arctic browning: extreme events and trends reversing arctic greening, Glob. Change Biol., 22, 2960-2962, https://doi.org/10.1111/gcb.13261, 2016.

Plante, S., Champagne, E., Ropars, P., Boudreau, S., Lévesque, E., Tremblay, B., and Tremblay, J.-P.: Shrub cover in northern Nunavik: can herbivores limit shrub expansion?, Polar Biol., 37, 611-619, 2014.

Pomeroy, J. W., Bewley, D. S., Essery, R. L. H., Hedstrom, N. R., Link, T., Granger, R. J., Sicart, J. E., Ellis, C. R., and Janowicz, J. R.: Shrub tundra snowmelt, Hydrol. Process, 20, 923-941, https://doi.org/10.1002/hyp.6124, 2006.

Ponomarev, E. I., Kharuk, V. I., and Ranson, K. J.: Wildfires dynamics in siberian larch forests, Forests, 7, 125, https://doi.org/10.3390/f7060125, 2016.

Poorter, H., Niklas, K. J., Reich, P. B., Oleksyn, J., Poot, P., and Mommer, L.: Biomass allocation to leaves, stems and roots: meta-analyses of interspecific variation and environmental control, New Phytol., 193, 30-50, 2012.

Racine, C., Jandt, R., Meyers, C., and Dennis, J.: Tundra fire and vegetation change along a hillslope on the Seward Peninsula, Alaska, USA, Arct. Antarct. Alp. Res., 36, 1-10, 2004.

Radville, L., McCormack, M. L., Post, E., and Eissenstat, D. M.: Root phenology in a changing climate, J. Exp. Bot., 67, 36173628, https://doi.org/10.1093/jxb/erw062, 2016.

Randerson, J. T., Liu, H., Flanner, M. G., Chambers, S. D., Jin, Y., Hess, P. G., Pfister, G., Mack, M. C., Treseder, K. K., Welp, L. R., Chapin, F. S., III, Harden, J. W., Goulden, M. L., Lyons, E., Neff, J. C., Schuur, E. A. G., and Zender, C. S.: The Impact of Boreal Forest Fire on Climate Warming, Science, 314, 1130-1132, https://doi.org/10.1126/science.1132075, 2006.

Rasmus, S., Lundell, R., and Saarinen, T.: Interactions between snow, canopy, and vegetation in a boreal coniferous forest, Plant Ecol. Divers., 4, 55-65, https://doi.org/10.1080/17550874.2011.558126, 2011.

Raynolds, M. K., Walker, D. A., Ambrosius, K. J., Brown, J., Everett, K. R., Kanevskiy, M., Kofinas, G. P., Romanovsky, V. E., Shur, Y., and Webber, P. J.: Cumulative geoecological effects of 62 years of infrastructure and climate change in ice-rich permafrost landscapes, Prudhoe Bay Oilfield, Alaska, Glob. Change Biol., 20, 1211-1224, https://doi.org/10.1111/gcb.12500, 2014.

Robinson, S. D. and Moore, T. R.: The influence of permafrost and fire upon carbon accumulation in high boreal peatlands, Northwest Territories, Canada, Arct. Antarct. Alp. Res., 32, 155-f166, https://doi.org/10.2307/1552447, 2000. 
Rocha, A. V. and Shaver, G. R.: Postfire energy exchange in arctic tundra: the importance and climatic implications of burn severity, Glob. Change Biol., 17, 2831-2841, https://doi.org/10.1111/j.1365-2486.2011.02441.x, 2011.

Rocha, A. V., Loranty, M. M., Higuera, P. E., Mack, M. C., Hu, F. S., Jones, B. M., Breen, A. L., Rastetter, E. B., Goetz, S. J., and Shaver, G. R.: The footprint of Alaskan tundra fires during the past half-century: implications for surface properties and radiative forcing, Environ. Res. Lett., 7, 044039, https://doi.org/10.1088/1748-9326/7/4/044039, 2012.

Romanovsky, V. E. and Osterkamp, T. E.: Interannual variations of the thermal regime of the active layer and near-surface permafrost in northern Alaska, Permafrost Periglac., 6, 313-335, https://doi.org/10.1002/ppp.3430060404, 1995.

Romanovsky, V. E. and Osterkamp, T. E.: Thawing of the active layer on the coastal plain of the Alaskan Arctic, Permafrost Periglac., 8, 1-22, 1997.

Romanovsky, V. E. and Osterkamp, T. E.: Effects of unfrozen water on heat and mass transport processes in the active layer and permafrost, Permafrost Periglac., 11, 219-239, 2000.

Romanovsky, V. E., Smith, S. L., and Christiansen, H. H.: Permafrost thermal state in the polar Northern Hemisphere during the international polar year 2007-2009: a synthesis, Permafrost Periglac., 21, 106-116, https://doi.org/10.1002/ppp.689, 2010.

Roy-Léveillée, P., Burn, C. R., and McDonald, I. D.: VegetationPermafrost Relations within the Forest-Tundra Ecotone near Old Crow, Northern Yukon, Canada, Permafrost Periglac., 25, 127135, https://doi.org/10.1002/ppp.1805, 2014.

Rydén, B. E. and Kostov, L.: Thawing and freezing in tundra soils, Ecol. Bull., 30, 251-281, 1980.

Schulze, E.-D., Wirth, C., Mollicone, D., von Lüpke, N., Ziegler, W., Achard, F., Mund, M., Prokushkin, A., and Scherbina, S.: Factors promoting larch dominance in central Siberia: fire versus growth performance and implications for carbon dynamics at the boundary of evergreen and deciduous conifers, Biogeosciences, 9, 1405-1421, https://doi.org/10.5194/bg-9-1405-2012, 2012.

Schuur, E. A. G., Crummer, K. G., Vogel, J. G., and Mack, M. C.: Plant Species Composition and Productivity following Permafrost Thaw and Thermokarst in Alaskan Tundra, Ecosystems, 10, 280-292, https://doi.org/10.1007/s10021-007-9024-0, 2007.

Schuur, E. A. G., Abbott, B. W., Bowden, W. B., Brovkin, V., Camill, P., Canadell, J. G., Chanton, J. P., Chapin, F. S., Christensen, T. R., Ciais, P., Crosby, B. T., Czimczik, C. I., Grosse, G., HARDEN, J., Hayes, D. J., Hugelius, G., Jastrow, J. D., Jones, J. B., Kleinen, T., Koven, C. D., Krinner, G., Kuhry, P., Lawrence, D. M., Mcguire, A. D., Natali, S. M., O’Donnell, J. A., Ping, C. L., Riley, W. J., Rinke, A., Romanovsky, V. E., Sannel, A. B. K., Schädel, C., Schaefer, K., Sky, J., Subin, Z. M., Tarnocai, C., Turetsky, M. R., WALDROP, M. P., Anthony, K. M. W., WICKLAND, K. P., Wilson, C. J., and Zimov, S. A.: Expert assessment of vulnerability of permafrost carbon to climate change, Climatic Change, 119, 359-374, https://doi.org/10.1007/s10584013-0730-7, 2013.

Schuur, E. A. G., Mcguire, A. D., Schädel, C., Grosse, G., Harden, J. W., Hayes, D. J., Hugelius, G., Koven, C. D., Kuhry, P., Lawrence, D. M., Natali, S. M., Olefeldt, D., Romanovsky, V. E., Schaefer, K., Turetsky, M. R., Treat, C. C., and Vonk, J. E.: Climate change and the permafrost carbon feedback, Nature, 520, 171-179, https://doi.org/10.1038/nature14338, 2015.
Shiklomanov, N. I., Streletskiy, D. A., Nelson, F. E., Hollister, R. D., Romanovsky, V. E., Tweedie, C. E., Bockheim, J. G., and Brown, J.: Decadal variations of active-layer thickness in moisturecontrolled landscapes, Barrow, Alaska, J. Geophys. Res., 115, G00I04, https://doi.org/10.1029/2009JG001248, 2010.

Shur, Y. L. and Jorgenson, M. T.: Patterns of permafrost formation and degradation in relation to climate and ecosystems, Permafrost Periglac., 18, 7-19, https://doi.org/10.1002/ppp.582, 2007.

Sjöberg, Y., Coon, E., K Sannel, A. B., Pannetier, R., Harp, D., Frampton, A., Painter, S. L., and Lyon, S. W.: Thermal effects of groundwater flow through subarctic fens: A case study based on field observations and numerical modeling, Water Resour. Res., 52, 1591-1606, https://doi.org/10.1002/2015WR017571, 2016.

Slater, A. G. and Lawrence, D. M.: Diagnosing Present and Future Permafrost from Climate Models, J. Climate, 26, 5608-5623, https://doi.org/10.1175/JCLI-D-12-00341.1, 2013.

Smith, M. W.: Microclimatic Influences on Ground Temperatures and Permafrost Distribution, Mackenzie Delta, Northwest Territories, Can. J. Earth Sci., 12, 1421-1438, https://doi.org/10.1139/e75-129, 1975.

Sofronov, M. and Volokitina, A.: Wildfire Ecology in Continuous Permafrost Zone, in Permafrost Ecosystems Siberian Larch Forests, edited by: Osawa, A., Zyryanova, O. A., Matsuura, Y., Kajimoto, T., and Wein, R. W., Springer, New York, 2010.

Soudzilovskaia, N. A., Van Bodegom, P. M., and Cornelissen, J. H. C.: Dominant bryophyte control over high-latitude soil temperature fluctuations predicted by heat transfer traits, field moisture regime and laws of thermal insulation, edited by: Schweitzer, J., Funct. Ecol., 27, 1442-1454, https://doi.org/10.1111/13652435.12127, 2013.

Stiegler, C., Johansson, M., Christensen, T. R., Mastepanov, M., and Lindroth, A.: Tundra permafrost thaw causes significant shifts in energy partitioning, Tellus B, 68, 1-11, https://doi.org/10.3402/tellusb.v68.30467, 2016a.

Stiegler, C., Lund, M., Christensen, T. R., Mastepanov, M., and Lindroth, A.: Two years with extreme and little snowfall: effects on energy partitioning and surface energy exchange in a high-Arctic tundra ecosystem, The Cryosphere, 10, 1395-1413, https://doi.org/10.5194/tc-10-1395-2016, 2016b.

Stieglitz, M.: The role of snow cover in the warming of arctic permafrost, Geophys. Res. Lett., 30, 1-4, https://doi.org/10.1029/2003GL017337, 2003.

Stoy, P. C., Street, L. E., Johnson, A. V., Prieto-Blanco, A., and Ewing, S. A.: Temperature, Heat Flux, and Reflectance of Common Subarctic Mosses and Lichens under Field Conditions: Might Changes to Community Composition Impact ClimateRelevant Surface Fluxes?, Arct. Antarct. Alp. Res., 44, 500-508, https://doi.org/10.1657/1938-4246-44.4.500, 2012.

Sturm, M., Holmgren, J., and Liston, G. E.: A seasonal snow cover classification system for local to global applications, J. Climate, 8, 1261-1283, https://doi.org/10.1175/15200442(1995)008<1261:assccs>2.0.co;2, 1995.

Sturm, M., McFadden, J., Liston, G. E., and Chapin III, F. S.: SnowShrub Interactions in Arctic Tundra: A Hypothesis with Climatic Implications, J. Climate, 14, 336-344, 2001.

Sturm, M., Douglas, T., Racine, C., and Liston, G. E.: Changing snow and shrub conditions affect albedo with 
global implications, J. Geophys. Res., 110, G01004, https://doi.org/10.1029/2005jg000013, 2005.

Swann, A. L., Fung, I. Y., Levis, S., Bonan, G. B., and Doney, S. C.: Changes in Arctic vegetation amplify high-latitude warming through the greenhouse effect, P. Natl. Acad. Sci. USA, 107, 1295-1300, https://doi.org/10.1073/pnas.0913846107, 2010.

Tape, K., Sturm, M., and Racine, C.: The evidence for shrub expansion in Northern Alaska and the Pan-Arctic, Glob. Change Biol., 12, 686-702, https://doi.org/10.1111/gcb.2006.12.issue-4, 2006.

Tchebakova, N., Parfenova, E., and Soja, A.: The effects of climate, permafrost and fire on vegetation change in Siberia in a changing climate, Environ. Res. Lett., 4, 045013, https://doi.org/10.1088/1748-9326/4/4/045013, 2009.

te Beest, M., Sitters, J., Ménard, C. B., and Olofsson, J.: Reindeer grazing increases summer albedo by reducing shrub abundance in Arctic tundra, Environ. Res. Lett., 11, 125013-125014, https://doi.org/10.1088/1748-9326/aa5128, 2016.

Turetsky, M. R., Kane, E. S., Harden, J. W., Ottmar, R. D., Manies, K. L., Hoy, E., and Kasischke, E. S.: Recent acceleration of biomass burning and carbon losses in Alaskan forests and peatlands, Nat. Geosci., 4, 27-31, https://doi.org/10.1038/ngeo1027, 2011.

Urban, M., Forkel, M., Schmullius, C., Hese, S., Hüttich, C., and Herold, M.: Identification of land surface temperature and albedo trends in AVHRR Pathfinder data from 1982 to 2005 for northern Siberia, Int. J. Remote Sens., 34, 4491-4507, 2013.

van der Wal, R., van Lieshout, S. M. J., and Loonen, M. J. J. E.: Herbivore impact on moss depth, soil temperature and arctic plant growth, Polar Biol., 24, 29-32, https://doi.org/10.1007/s003000000170, 2001.

Vavrek, M. C., Fetcher, N., McGraw, J. B., Shaver, G. R., Chapin III, F. S., and Bovard, B.: Recovery of productivity and species diversity in tussock tundra following disturbance, Arct. Antarct. Alp. Res., 31, 254-258, 1999.

Väisänen, M., Ylänne, H., Kaarlejärvi, E., Sjögersten, S., Olofsson, J., Crout, N., and Stark, S.: Consequences of warming on tundra carbon balance determined by reindeer grazing history, Nat. Clim. Change, 4, 384-388, https://doi.org/10.1038/nclimate2147, 2014.

Viereck, L. A., Werdin-Pfisterer, N. R., Adams, P. C., and Yoshikawa, K.: Effect of wildfire and fireline construction on the annual depth of thaw in a black spruce permafrost forest in interior Alaska: a 36-year record of recovery, Proceedings of the Ninth International Conference on Permafrost, 1845-1850, 2008.

Voigt, C., Marushchak, M. E., Lamprecht, R. E., JackowiczKorczynski, M., Lindgren, A., Mastepanov, M., Granlund, L., Christensen, T. R., Tahvanainen, T., Martikainen, P. J., and Biasi, C.: Increased nitrous oxide emissions from Arctic peatlands after permafrost thaw, P. Natl. Acad. Sci. USA, 114, 6238-6243, https://doi.org/10.1073/pnas.1702902114, 2017.

Wagner, A. M., Lindsey, N. J., Dou, S., Gelvin, A., Saari, S., Williams, C., Ekblaw, I., Ulrich, C., Borglin, S., Morales, A., and Ajo-Franklin, J.: Permafrost Degradation and Subsidence Observations during a Controlled Warming Experiment, Scientific Reports, 8, 10908, https://doi.org/10.1038/s41598-018-29292-y, 2018.
Walker, D. A. and Everett, K. R.: Road dust and its environmental impact on Alaskan taiga and tundra, Arct. Alp. Res., 19, 479489, 1987.

Walker, D. A., Webber, P. J., Binnian, E. F., Everett, K. R., Lederer, N. D., Nordstrand, E. A., and Walker, M. D.: Cumulative impacts of oil fields on northern Alaskan landscapes, Science, 238, 757761, 1987.

Walker, D. and Everett, K.: Loess ecosystems of northern Alaska: regional gradient and toposequence at Prudhoe Bay, Ecol. Monogr., 61, 437-464, 1991.

Walker, D. A., Billings, W. D., and De Molenaar, J. G.: Snowvegetation interactions in tundra environments, Snow ecology: an interdisciplinary examination of snow-covered ecosystems, 266324, 2001.

Walker, M., Wahren, C., Hollister, R., Henry, G., Ahlquist, L. E., Alatalo, J. M., Bret-Harte, M. S., Calef, M. P., Callaghan, T. V., Carroll, A. B., Epstein, H. E., Jonsdottir, I. S., Klein, J. A., Magnusson, B., Molau, U., Oberbauer, S. F., Rewa, S. P., Robinson, C. H., Shaver, G. R., Suding, K. N., Thompson, C. C., Tolvanen, A., Totland, O., Turner, P. L., Webber, C. E. T. J., and Wookey, P. A.: Plant community responses to experimental warming across the tundra biome, P. Natl. Acad. Sci. USA, 103, 1342-1346, 2006.

Walker, X. and Johnstone, J. F.: Widespread negative correlations between black spruce growth and temperature across topographic moisture gradients in the boreal forest, Environ. Res. Lett., 9, 064016, https://doi.org/10.1088/1748-9326/9/6/064016, 2014.

Walker, X. J., Mack, M. C., and Johnstone, J. F.: Stable carbon isotope analysis reveals widespread drought stress in boreal black spruce forests, Glob. Change Biol., 21, 3102-3113, https://doi.org/10.1111/gcb.12893, 2015.

Walter, K. M., Smith, L. C., and Stuart Chapin, F.: Methane bubbling from northern lakes: present and future contributions to the global methane budget, Philos. T. Roy. Soc. A, 365, 1657-1676, https://doi.org/10.1098/rsta.2007.2036, 2007.

Walter, K. M., Chanton, J. P., Chapin, F. S., Schuur, E. A. G., and Zimov, S. A.: Methane production and bubble emissions from arctic lakes: Isotopic implications for source pathways and ages, J. Geophys. Res., 113, G00A08, https://doi.org/10.1029/2007JG000569, 2008.

Webb, E. E., Heard, K., Natali, S. M., Bunn, A. G., Alexander, H. D., Berner, L. T., Kholodov, A., Loranty, M. M., Schade, J. D., Spektor, V., and Zimov, N.: Variability in above- and belowground carbon stocks in a Siberian larch watershed, Biogeosciences, 14, 4279-4294, https://doi.org/10.5194/bg-14-42792017, 2017.

Webster, C., Rutter, N., Zahner, F., and Jonas, T.: Measurement of Incoming Radiation below Forest Canopies: A Comparison of Different Radiometer Configurations, J. Hydrometeorol., 17, 853-864, https://doi.org/10.1175/JHM-D-15-0125.1, 2016.

Welp, L. R., Patra, P. K., Rödenbeck, C., Nemani, R., Bi, J., Piper, S. C., and Keeling, R. F.: Increasing summer net $\mathrm{CO}_{2}$ uptake in high northern ecosystems inferred from atmospheric inversions and comparisons to remote-sensing NDVI, Atmos. Chem. Phys., 16, 9047-9066, https://doi.org/10.5194/acp-16-9047-2016, 2016.

Williamson, S. N., Barrio, I. C., Hik, D. S., and Gamon, J. A.: Phenology and species determine growing-season albedo increase at the altitudinal limit of shrub growth 
in the sub-Arctic, Glob. Change Biol., 22, 3621-3631, https://doi.org/10.1111/gcb.13297, 2016.

Woo, M.: Consequences of climatic change for hydrology in permafrost zones, J. Cold Reg. Eng., 4, 15-20, https://doi.org/10.1061/(ASCE)0887-381X(1990)4:1(15), 1990.

Woo, M.-K., Mollinga, M., and Smith, S. L.: Climate warming and active layer thaw in the boreal and tundra environments of the Mackenzie Valley, Can. J. Earth Sci., 44, 733-743, https://doi.org/10.1139/e06-121, 2007.

Xue, X., Peng, F., You, Q., Xu, M., and Dong, S.: Belowground carbon responses to experimental warming regulated by soil moisture change in an alpine ecosystem of the Qinghai-Tibet Plateau, Ecol. Evol., 5, 4063-4078, 2015.

Yi, S., Mcguire, A. D., Harden, J., Kasischke, E., Manies, K., Hinzman, L., Liljedahl, A., Randerson, J., Liu, H., Romanovsky, V., Marchenko, S., and Kim, Y.: Interactions between soil thermal and hydrological dynamics in the response of Alaska ecosystems to fire disturbance, J. Geophys. Res., 114, 1-20, https://doi.org/10.1029/2008JG000841, 2009.

Yoshikawa, K. and Hinzman, L. D.: Shrinking thermokarst ponds and groundwater dynamics in discontinuous permafrost near council, Alaska, Permafrost Periglac., 14, 151-160, https://doi.org/10.1002/ppp.451, 2003.

Yoshikawa, K., Bolton, W. R., Romanovsky, V. E., Fukuda, M., and Hinzman, L. D.: Impacts of wildfire on the permafrost in the boreal forests of Interior Alaska, J. Geophys. Res., 108, 8148, https://doi.org/10.1029/2001JD000438, 2003.
Zamin, T. J. and Grogan, P.: Birch shrub growth in the low Arctic: the relative importance of experimental warming, enhanced nutrient availability, snow depth and caribou exclusion, Environ. Res. Lett., 7, 034027-10, https://doi.org/10.1088/17489326/7/3/034027, 2012.

Zeng, Z., Piao, S., Li, L. Z. X., Zhou, L., Ciais, P., Wang, T., Li, Y., Lian, X., Wood, E. F., Friedlingstein, P., Mao, J., Estes, L. D., Myneni, R. B., Peng, S., Shi, X., Seneviratne, S. I., and Wang, Y.: Climate mitigation from vegetation biophysical feedbacks during the past three decades, Nat. Clim. Change, 351, 600-608, https://doi.org/10.1038/nclimate3299, 2017.

Zhang, K., Kimball, J. S., Mu, Q., Jones, L. A., Goetz, S. J., and Running, S. W.: Satellite based analysis of northern ET trends and associated changes in the regional water balance from 1983 to 2005, J. Hydrol., 379, 92-110, https://doi.org/10.1016/j.jhydrol.2009.09.047, 2009.

Zhang, T.: Influence of the seasonal snow cover on the ground thermal regime: An overview, Rev. Geophys., 43, RG4002, https://doi.org/10.1029/2004RG000157, 2005.

Zhang, T., Heginbottom, J. A., Barry, R. G., and Brown, J.: Further statistics on the distribution of permafrost and ground ice in the Northern Hemisphere, Polar Geography, 24, 126-131, 2000.

Zimov, S. A., Zimov, N. S., Tikhonov, A. N., and Chapin III, F. S.: Mammoth steppe: a high-productivity phenomenon, Quaternary Sci. Rev., 57, 26-45, https://doi.org/10.1016/j.quascirev.2012.10.005, 2012. 